\title{
Anion and Cation Permeability of the Mouse TMEM16F Calcium-Activated Channel
}

\author{
Stefano Stabilini ${ }^{1,+}$, Anna Menini ${ }^{1,+}$ and Simone Pifferi $1,2, *$ (D) \\ 1 Neurobiology Group, SISSA, International School for Advanced Studies, 34136 Trieste, Italy; \\ stabilini.stefano@gmail.com (S.S.); menini@sissa.it (A.M.) \\ 2 Department of Experimental and Clinical Medicine, Università Politecnica delle Marche, 60126 Ancona, Italy \\ * Correspondence: s.pifferi@staff.univpm.it \\ † Present adress: Metrion Biosciences Ltd., Cambridge CB21 6AD, UK.
}

Citation: Stabilini, S.; Menini, A.;

Pifferi, S. Anion and Cation Permeability of the Mouse TMEM16F Calcium-Activated Channel. Int. J. Mol. Sci. 2021, 22, 8578. https:// doi.org/10.3390/ijms22168578

Academic Editor: Settimio Rossi

Received: 6 July 2021

Accepted: 4 August 2021

Published: 9 August 2021

Publisher's Note: MDPI stays neutral with regard to jurisdictional claims in published maps and institutional affiliations.

Copyright: (c) 2021 by the authors. Licensee MDPI, Basel, Switzerland. This article is an open access article distributed under the terms and conditions of the Creative Commons Attribution (CC BY) license (https:// creativecommons.org/licenses/by/ $4.0 /)$.

\begin{abstract}
TMEM16F is involved in several physiological processes, such as blood coagulation, bone development and virus infections. This protein acts both as a $\mathrm{Ca}^{2+}$-dependent phospholipid scramblase and a $\mathrm{Ca}^{2+}$-activated ion channel but several studies have reported conflicting results about the ion selectivity of the TMEM16F-mediated current. Here, we have performed a detailed side-by-side comparison of the ion selectivity of TMEM16F using the whole-cell and inside-out excised patch configurations to directly compare the results. In inside-out configuration, $\mathrm{Ca}^{2+}$-dependent activation was fast and the TMEM16F-mediated current was activated in a few milliseconds, while in whole-cell recordings full activation required several minutes. We determined the relative permeability between $\mathrm{Na}^{+}$and $\mathrm{Cl}^{-}\left(\mathrm{P}_{\mathrm{Na}} / \mathrm{P}_{\mathrm{Cl}}\right)$ using the dilution method in both configurations. The TMEM16F-mediated current was highly nonselective, but there were differences depending on the configuration of the recordings. In whole-cell recordings, $\mathrm{P}_{\mathrm{Na}} / \mathrm{P}_{\mathrm{Cl}}$ was approximately 0.5 , indicating a slight preference for $\mathrm{Cl}^{-}$permeation. In contrast, in inside-out experiments the TMEM16F channel showed a higher permeability for $\mathrm{Na}^{+}$with $\mathrm{P}_{\mathrm{Na}} / \mathrm{P}_{\mathrm{Cl}}$ reaching 3.7. Our results demonstrate that the time dependence of $\mathrm{Ca}^{2+}$ activation and the ion selectivity of TMEM16F depend on the recording configuration.
\end{abstract}

Keywords: ion channel; electrophysiology; permeability

\section{Introduction}

The TMEM16 (also named anoctamin or ANO) family is a heterogeneous functional group of ten transmembrane proteins [1-4]. The first two members, TMEM16A (ANO1) and TMEM16B (ANO2), encode for $\mathrm{Ca}^{2+}$-activated $\mathrm{Cl}^{-}$channels [5-9] and are involved in several relevant physiological functions, such as control of fluid secretion, modulation of smooth muscle cell excitability, regulation of neuronal signalling in various brain regions and in olfactory and vomeronasal sensory neurons [1,10-14]. TMEM16F (ANO6) and most of the other members of the TMEM16 family, with the exception of TMEM16H (ANO8), function as both $\mathrm{Ca}^{2+}$-activated lipid scramblases and ion channels $[15,16]$.

Scramblases mediate the diffusion of phospholipids between the two leaflets of the membrane following their chemical gradient. For example, the activation of scramblases allows phosphatidylserine, that is normally localised in the inner leaflet of the membrane, to be exposed to the cell surface, generating a signal for several physiological processes, such as phagocytosis of apoptotic cells, blood coagulation and bone mineralisation [17]. Suzuki et al., (2010) first showed that TMEM16F is a $\mathrm{Ca}^{2+}$-activated phospholipid scramblase and that loss-of-function TMEM16F mutations cause the Scott syndrome, a human bleeding disorder caused by a defect in phospholipid scrambling $[16,18]$. TMEM16F is also involved in bone development [19], microglial response to injury [20] and virus infections $[21,22]$.

TMEM16F, besides being a scramblase, also mediates $\mathrm{Ca}^{2+}$-activated ion channel activity [23] but several discrepancies have been reported regarding the properties of the 
TMEM16F-mediated current, especially about ion selectivity [24,25]. Indeed, although all reports agree that TMEM16F is a poorly selective channel, several studies performed in whole-cell recordings from TMEM16F heterologously expressed in HEK-293 cells reported a slightly higher permeability to $\mathrm{Cl}^{-}$than to $\mathrm{Na}^{+}$[26-33]. On the contrary, recordings using inside-out excised patches showed that TMEM16F was more permeable to cations than to anions $[23,34,35]$. The TMEM16F Q559K mutant was shown to have a reduced permeability ratio $\mathrm{P}_{\mathrm{Na}} / \mathrm{P}_{\mathrm{Cl}}$ compared to TMEM16F wild type (wt) when measured in inside-out patches [23], while its ion selectivity in the whole-cell configuration has not been reported yet. Furthermore, a recent study suggested that TMEM16F has a dynamic ion selectivity that depends on $\mathrm{Ca}^{2+}$ concentration [36].

As most studies of ion selectivity were obtained by different laboratories using one of the two patch-clamp configurations with different $\mathrm{Ca}^{2+}$ concentrations and ionic conditions, in this study we asked whether there is a difference in ion selectivity of the TMEM16F channel in different recording configurations. We performed a side-by-side comparison of the electrophysiological properties of the TMEM16F wt and Q559K mutant using both whole-cell and inside-out configurations with the same ionic solutions. We found that both the time dependence of $\mathrm{Ca}^{2+}$ activation and ion selectivity depend on the recording configuration.

\section{Results}

\section{1. $\mathrm{Ca}^{2+}$ Activation of the TMEM16F wt Current in Whole-Cell and Inside-Out Configurations}

We compared the $\mathrm{Ca}^{2+}$-dependent activation of TMEM16F wt currents between wholecell and inside-out patch-clamp recordings. Figure 1A shows a representative recording in whole-cell configuration obtained by dialyzing HEK-293 TMEM16F wt-expressing cells with a pipette solution containing $100 \mu \mathrm{M} \mathrm{Ca}^{2+}$ and recording the current induced by repeated voltage steps to $+80 \mathrm{mV}$ applied every $10 \mathrm{~s}$ from the holding potential of $0 \mathrm{mV}$. The current amplitude gradually increased with time after membrane breaking, reaching a steady state level after approximately $2.5 \mathrm{~min}$ (Figure 1B). Recordings with intracellular free $\mathrm{Ca}^{2+}$ concentrations varying from 3.8 to $500 \mu \mathrm{M}$ showed that the time necessary to activate the TMEM16F wt current significantly increased with lower intracellular $\mathrm{Ca}^{2+}$, ranging from about $2.5 \mathrm{~min}$ at 100 and $500 \mu \mathrm{M} \mathrm{Ca}^{2+}$ to about $20 \mathrm{~min}$ at $3.8 \mu \mathrm{M} \mathrm{Ca}^{2+}$ (Figure 1C). Control experiments with HEK-293 transfected with TMEM16A or TMEM16B did not show a significant delay between membrane breaking and current activation, ruling out a possible role of slow $\mathrm{Ca}^{2+}$ diffusion in the delayed current activation (Figure S1).

In inside-out patches, we measured the $\mathrm{Ca}^{2+}$-dependent activation by using a perfusion system that allows a fast change of solution in less than $10 \mathrm{~ms}$ [8]. Figure 1D shows currents activated by the exposure of the cytoplasmic side of a patch to $1 \mathrm{mM} \mathrm{Ca}^{2+}$ for $2 \mathrm{~s}$ at the holding potential of $+50 \mathrm{mV}$. Unlike the results obtained in whole-cell recordings with free $\mathrm{Ca}^{2+}$ in the patch pipette, the TMEM16F current was rapidly activated upon application of $1 \mathrm{mM} \mathrm{Ca}^{2+}$ and the time course of $\mathrm{Ca}^{2+}$-dependent activation was well fitted with the double-exponential function with time constants of $15 \pm 2 \mathrm{~ms}$ and $105 \pm 31 \mathrm{~ms}(\mathrm{n}=19)$. Moreover, the TMEM16F wt current underwent an irreversible decrease in amplitude with time, a process that we define as rundown (Figure 1D,E). To determine the time course of the rundown, we repeatedly exposed the excised inside-out patches to $1 \mathrm{mM} \mathrm{Ca}^{2+}$ for $2 \mathrm{~s}$ every $15 \mathrm{~s}$, keeping them in the nominally $0 \mathrm{Ca}^{2+}$ solution between $\mathrm{Ca}^{2+}$ applications. Subsequent exposures to $\mathrm{Ca}^{2+}$ produced currents of decreasing amplitudes (Figure 1D,E). We measured the peak current after each $\mathrm{Ca}^{2+}$ application and calculated the ratio between the values obtained at various times after patch excision and the maximal current measured $10 \mathrm{~s}$ after patch excision. The rundown was fast in the first minute after patch excision and then slowed down with time and the current sometimes reached a stationary current level. After $2.5 \mathrm{~min}$, the average TMEM16F wt current decreased to $7 \pm 1 \%(n=31)$ of the starting value (Figure 1E). In contrast, no significant rundown was observed in whole-cell recordings after reaching the steady state level (Figure S2).

To determine the $\mathrm{Ca}^{2+}$ sensitivity of the TMEM16F wt-mediated current in wholecell configuration, we performed experiments dialyzing various cells with intracellular 
solutions containing different free $\mathrm{Ca}^{2+}$ concentrations. Figure 2A shows currents activated by voltage steps of $2.5 \mathrm{~s}$ from $-100 \mathrm{mV}$ to $+100 \mathrm{mV}$ in $20 \mathrm{mV}$ intervals, given from a holding potential of $0 \mathrm{mV}$. Currents were measured at the time they reached the maximal activation as shown in Figure 1A-C. Unlike the results obtained with TMEM16A and TMEM16B [5-9,37,38], we did not observe a significant change in the rectification of TMEM16F wt depending on the intracellular $\mathrm{Ca}^{2+}$, but we measured a strong outward rectification at every $\mathrm{Ca}^{2+}$ concentration (Figure 2B). Indeed, the ratio between the current measured at the end of voltage pulses at +100 and $-100 \mathrm{mV}$ was $22 \pm 8(\mathrm{n}=6)$ in the presence of $3.8 \mu \mathrm{M} \mathrm{Ca}^{2+}$ and $20 \pm 13$ with $100 \mu \mathrm{M} \mathrm{Ca}^{2+}(\mathrm{n}=7, p=0.28$ Wilcoxon-MannWhitney test). To analyse the $\mathrm{Ca}^{2+}$-dependence of TMEM16F wt activation at various voltages, we plotted the average current density measured at the end of voltage pulse versus $\mathrm{Ca}^{2+}$ concentration and fitted the data with the Hill equation $\mathrm{D}=\mathrm{D}_{\max }\left[\mathrm{c}^{\mathrm{n}} \mathrm{H} /\left(\mathrm{c}^{\mathrm{n}} \mathrm{H}+\right.\right.$ $\left.K_{1 / 2}{ }^{n} H\right)$ ], where $D$ is the current density, $D_{\max }$ is the maximal current density, $\mathrm{c}$ is the $\mathrm{Ca}^{2+}$ concentration, $\mathrm{K}_{1 / 2}$ is the $\mathrm{Ca}^{2+}$ concentration producing half-maximal current activation and $\mathrm{n}_{\mathrm{H}}$ is the Hill coefficient. $\mathrm{K}_{1 / 2}$ slightly decreased with membrane depolarisation from $22.2 \mu \mathrm{M}$ at $+60 \mathrm{mV}$ to $17.4 \mu \mathrm{M}$ at $+100 \mathrm{mV}$, while the Hill coefficient ranged from 1.6 to 3.8 (Figure 2C,F).

In inside-out patches, we measured the dependence of the TMEM16F wt-induced current on the intracellular $\mathrm{Ca}^{2+}$ concentration by exposing every single patch to solutions containing various $\mathrm{Ca}^{2+}$ concentrations. Each patch was kept in nominally $0 \mathrm{Ca}^{2+}$ solution, exposed for $1 \mathrm{~s}$ to $1 \mathrm{mM} \mathrm{Ca}^{2+}$ and returned to $0 \mathrm{Ca}^{2+}$ for $1 \mathrm{~s}$ to make sure that all $\mathrm{Ca}^{2+}$ was removed. Then the patch was exposed to increasing $\mathrm{Ca}^{2+}$ concentrations in the range between 3.8 and $100 \mu \mathrm{M}$ and returned to 0 . Finally, a test with $1 \mathrm{mM} \mathrm{Ca}^{2+}$ was repeated to establish if there was rundown of the current. Experiments were performed just after patch excision and currents measured at different $\mathrm{Ca}^{2+}$ concentrations were normalised to the average value obtained with $1 \mathrm{mM} \mathrm{Ca}^{2+}$ before and after the application of various test $\mathrm{Ca}^{2+}$ concentrations to minimise the possible effect of rundown. Figure 2D illustrates the results of representative dose-response experiments at the holding potentials of $+60 \mathrm{mV}$ and $+100 \mathrm{mV}$. Normalised currents versus the $\mathrm{Ca}^{2+}$ concentration are plotted in Figure 2E and fitted by the Hill equation: $\mathrm{I} / \mathrm{I}_{\max }=\mathrm{c}^{\mathrm{nH}} /\left(\mathrm{c}^{\mathrm{nH}}+K_{1 / 2}{ }^{\mathrm{nH}}\right)$, where $\mathrm{c}$ is the $\mathrm{Ca}^{2+}$ concentration, $K_{1 / 2}$ is the $\mathrm{Ca}^{2+}$ concentration producing half-maximal current activation and $\mathrm{n}_{\mathrm{H}}$ is the Hill coefficient. Similar to the data obtained in whole cell recordings, $\mathrm{K}_{1 / 2}$ slightly decreased with membrane depolarisation from $43 \pm 6 \mu \mathrm{M}$ at $+60 \mathrm{mV}$ to $28 \pm 1 \mu \mathrm{M}$ at $+100 \mathrm{mV}$ $(\mathrm{n}=7-8 ; p=0.031$ unpaired $t$-test, Figure $2 \mathrm{~F}$ ), while the Hill coefficient ranged from 2.4 to 2.8. Although $K_{1 / 2}$ values measured in inside-out were significantly higher than those obtained from whole-cell recordings, they all ranged between 17.4 and $43 \mu \mathrm{M}$, indicating a low apparent affinity of TMEM16F wt for $\mathrm{Ca}^{2+}$ in both configurations. 


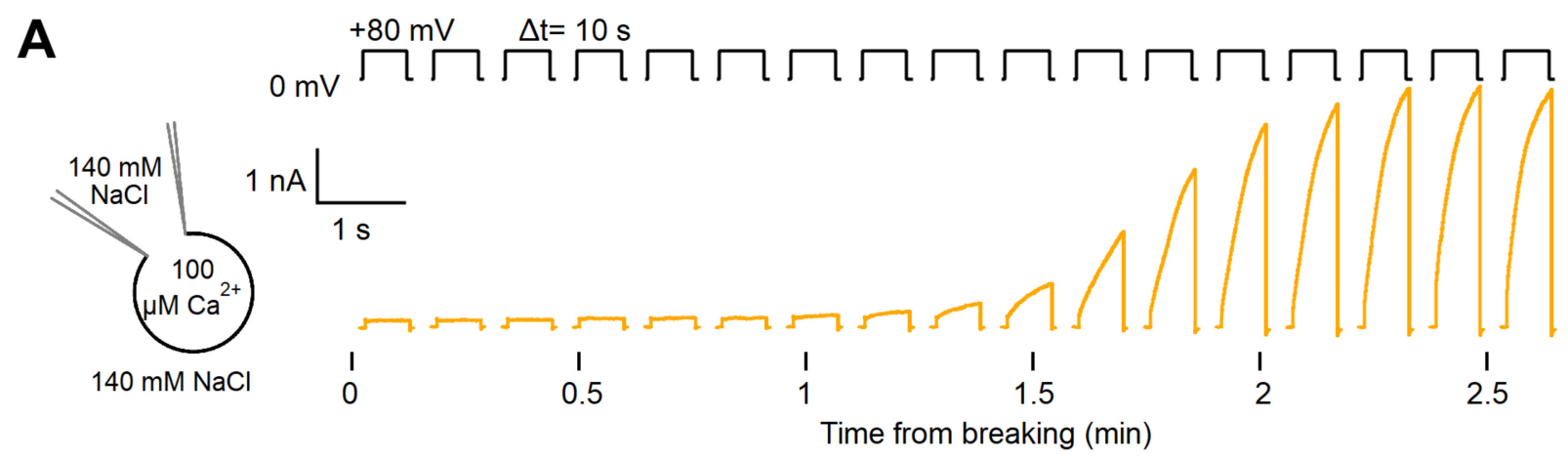

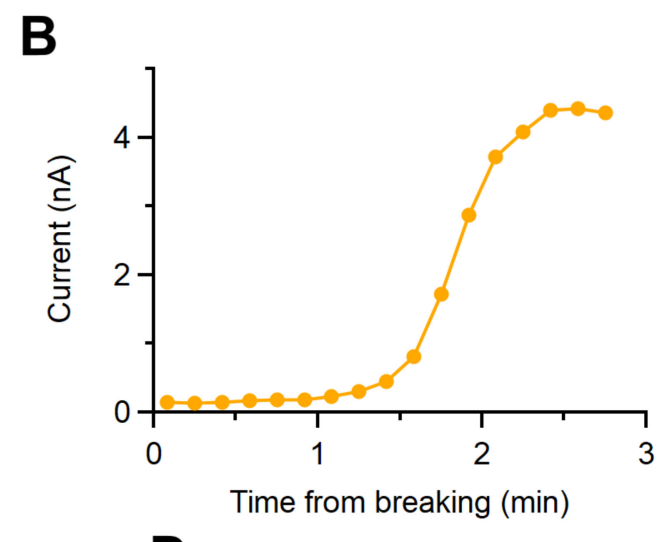

D

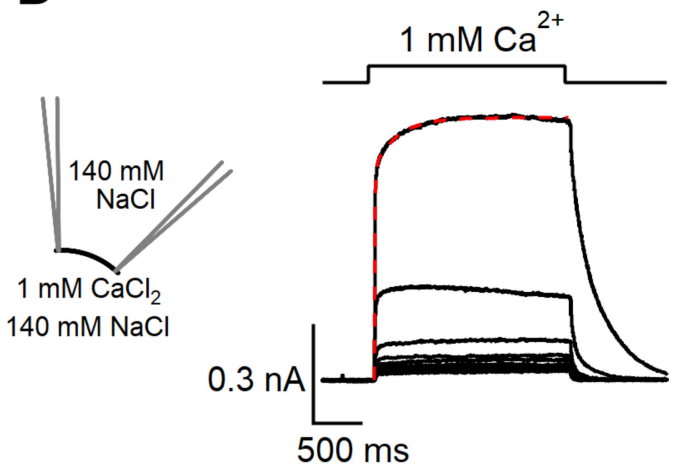

C

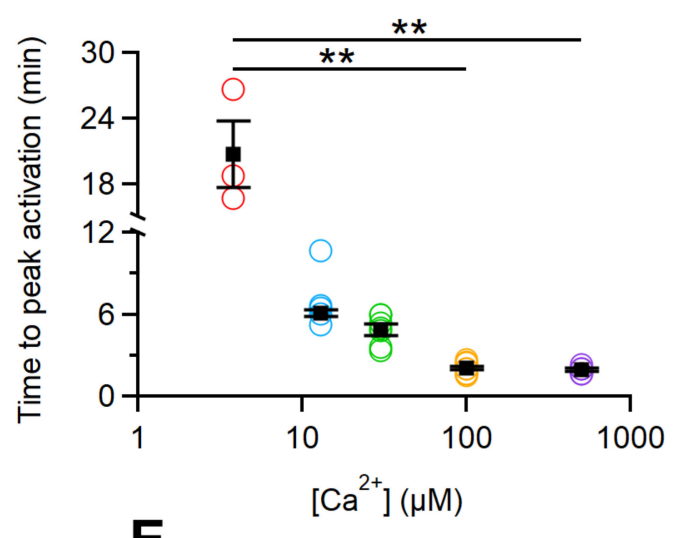

E

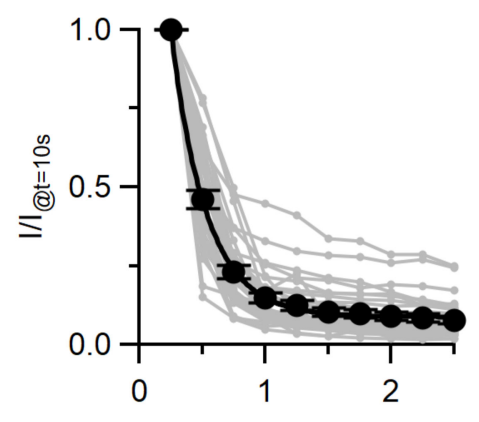

Time after patch excision (min)

Figure 1. Kinetics of $\mathrm{Ca}^{2+}$-dependent activation of the TMEM16F wt-mediated current. (A) Whole-cell recordings obtained from TMEM16F wt-transfected cells with a pipette solution containing $100 \mu \mathrm{M} \mathrm{Ca}^{2+}$. The development of the current with time was monitored by repeatedly applying a $+80 \mathrm{mV}$ step every $10 \mathrm{~s}$, as indicated in the upper traces. (B) Current amplitudes at the end of voltage steps were plotted against the time after membrane breaking for the recordings in (A). (C) The time required to obtain the maximal current activation was plotted against the intracellular $\mathrm{Ca}^{2+}$ concentration ( $\mathrm{n}=3-8,{ }^{* *} p<0.01$ Dunn-Holland-Wolf test after Kruskal-Wallis test). (D) An inside-out excised membrane patch expressing TMEM16F wt was repeatedly stimulated every $15 \mathrm{~s}$ with a solution containing $1 \mathrm{mM} \mathrm{Ca}^{2+}$ as indicated in the upper trace. The holding potential was $+60 \mathrm{mV}$. The red line superimposed to the upper trace is the fit with a double exponential function. (E) Ratios between the peak current values measured at various times after patch excision and the value measured after $10 \mathrm{~s}$ were plotted against the time after patch excision for several patches (grey dots and lines). Black circles are the average \pm sem from different patches $(n=31)$. The black line is the best fit to a single exponential. 
A

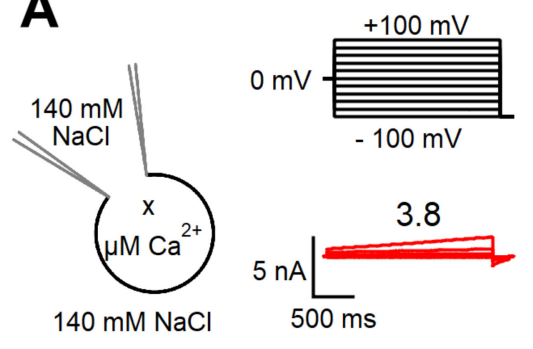

B

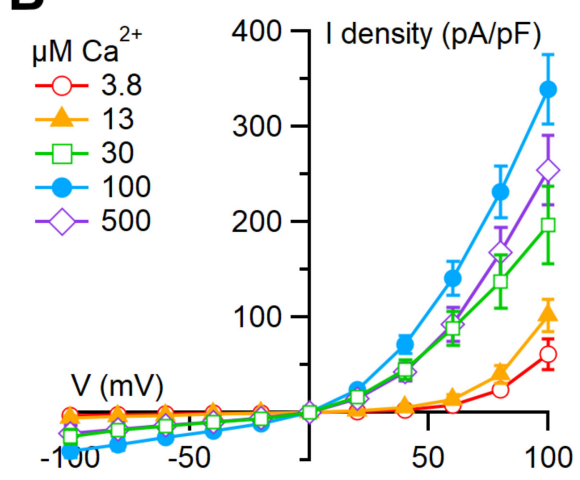

D

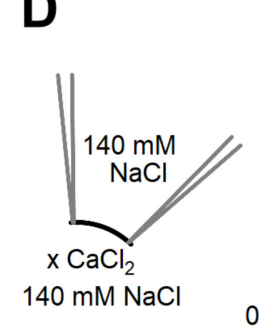

13

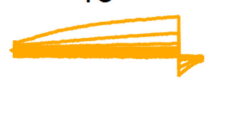

30

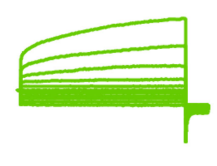

C

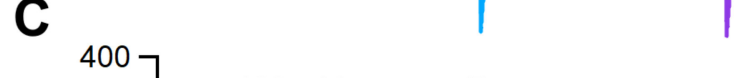

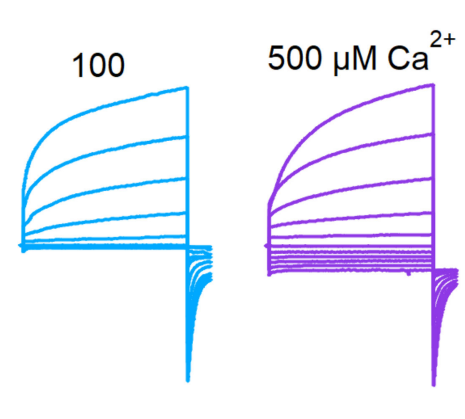

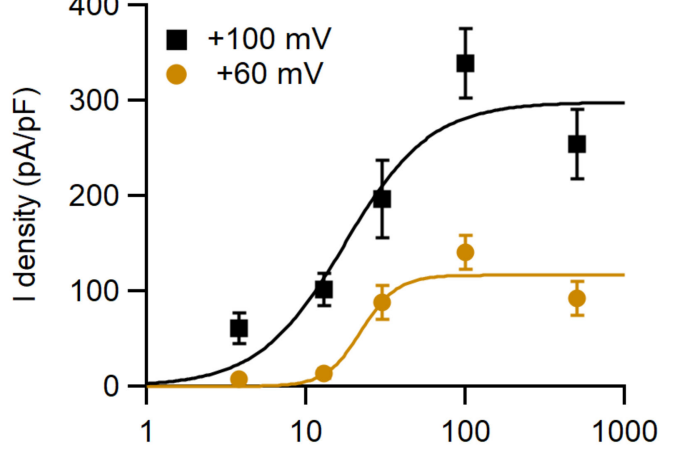

$\left[\mathrm{Ca}^{2+}\right](\mu \mathrm{M})$ 
voltage protocol is shown at the top of the panel. (B) Average steady-state IV relationships from several cells at the indicated $\mathrm{Ca}^{2+}$ concentrations $(\mathrm{n}=4-10)$. (C) Averages \pm sem of the current density at different voltages were plotted against $\mathrm{Ca}^{2+}$ concentration $(n=4-10)$. The continuous lines are the fit with the Hill equation. (D) An inside-out excised membrane patch expressing TMEM16F wt was kept in $0 \mathrm{Ca}^{2+}$ and exposed for $1 \mathrm{~s}$ to solutions containing different free $\mathrm{Ca}^{2+}$ concentrations (x) at the time indicated in the upper traces. The holding potential was $+60 \mathrm{mV}$, or $+100 \mathrm{mV}$ as indicated. (E) Dose-response relations of activation by $\mathrm{Ca}^{2+}$ obtained by normalised currents and fitted to the Hill equation. Current amplitudes were calculated as the average value in the last $50 \mathrm{~ms}$ to each $\mathrm{Ca}^{2+}$ exposure and the current amplitude in $0 \mathrm{Ca}^{2+}$ was subtracted. (F) Comparison of $\mathrm{K}_{1 / 2}$ obtained in different recording configurations ( $\mathrm{n}=7-8$ for inside out, ${ }^{*} p<0.05$ ).

\subsection{Comparison between Ion Selectivity of TMEM16F wt in Whole-Cell and Inside-Out Configurations}

To compare the ion selectivity of TMEM16F wt in the whole-cell and inside-out configurations we first investigated the permeability ratio between $\mathrm{Na}^{+}$and $\mathrm{Cl}^{-}$by diluting the external $\mathrm{NaCl}$ concentration from $140 \mathrm{mM}$ to $14 \mathrm{mM}$. As the I-V relations measured in whole-cell recordings showed a very pronounced outward rectification, we measured tail currents by first activating the channels with a prepulse at $+80 \mathrm{mV}$ followed by voltage steps between -20 and $+50 \mathrm{mV}$ (Figure 3A,B). It is interesting to note that the I-V relation obtained from tail currents measured at the beginning of each step was almost linear (Figures 3C and 5A), whereas the steady state I-V had a strong outward rectification (Figure 2B), clearly demonstrating that the I-V relation of the open channel was almost linear, and therefore the strong outward rectification mainly depends on voltage-dependent gating.

In whole-cell recordings, dilution of $\mathrm{NaCl}$ in the extracellular solution caused a positive shift of reversal potential to $14 \pm 1 \mathrm{mV}$ as expected for channels more permeable to anions than to cations (Figure 3C). The relative permeability ratio between $\mathrm{Na}^{+}$and $\mathrm{Cl}^{-}$ $\left(\mathrm{P}_{\mathrm{Na}} / \mathrm{P}_{\mathrm{Cl}}\right)$ calculated with the Goldman-Hodgkin-Katz equation was $0.52 \pm 0.03(\mathrm{n}=7$, Figure 3F), indicating that the TMEM16F wt channel was more permeable to $\mathrm{Cl}^{-}$than to $\mathrm{Na}^{+}$. Similar results were obtained also using voltage ramps (Figure S3).

In inside-out patches, reduction of the cytoplasmic $\mathrm{NaCl}$ concentration from 140 to $14 \mathrm{mM}$ caused a positive shift of the reversal potential to $25.5 \pm 0.6 \mathrm{mV}(\mathrm{n}=19)$, as expected for channels more permeable to cations than to anions. $\mathrm{P}_{\mathrm{Na}} / \mathrm{P}_{\mathrm{Cl}}$ was $3.7 \pm 0.1$ $(n=19)$, very different from the value of $0.52 \pm 0.03(n=7)$ calculated from whole-cell recordings (Figure 3F). Thus, the TMEM16F wt channel recorded in inside-out excised patches was more permeable to $\mathrm{Na}^{+}$than to $\mathrm{Cl}^{-}$, whereas it was the opposite in the whole-cell configuration. However, since $\mathrm{NaCl}$ concentrations were modified at different sides of the channel in the two patch-clamp configurations (Figure $3 C, F$ ), we reasoned that the different permeabilities could be due to an asymmetric channel pore. To test this possibility, we evaluated the ionic permeability in the inside-out configuration by reducing the $\mathrm{NaCl}$ concentration to $14 \mathrm{mM}$ in the pipette solution bathing the extracellular side of the membrane (Figure $3 \mathrm{E}$ ). The average reversal potential in these ionic conditions was $-26 \pm 2 \mathrm{mV}(\mathrm{n}=7)$ and $\mathrm{P}_{\mathrm{Na}} / \mathrm{P}_{\mathrm{Cl}}$ was $3.9 \pm 0.5(\mathrm{n}=7)$, showing that also in these experimental conditions $\mathrm{Na}^{+}$was more permeant than $\mathrm{Cl}^{-}$. Thus, the significant difference between $\mathrm{P}_{\mathrm{Na}} / \mathrm{P}_{\mathrm{Cl}}$ measured in whole-cell or in the inside-out configuration was not due to an asymmetric channel pore (Figure $3 \mathrm{~F}$ ).

Since using the dilution method could cause significant deviations from the expected value of $\mathrm{P}_{\mathrm{Na}} / \mathrm{P}_{\mathrm{Cl}}$ from the Goldman-Hodgkin-Katz equation [36,39], we tested this possibility in inside-out patches by varying the $\mathrm{NaCl}$ concentration in the bath solution from $14 \mathrm{mM}$ to $280 \mathrm{mM}$ (Figure 4A) and we found significant deviations from prediction of the Goldman-Hodgkin-Katz equation (Figure $4 \mathrm{~B}$ ). Indeed, $\mathrm{P}_{\mathrm{Na}} / \mathrm{P}_{\mathrm{Cl}}$ obtained with solutions containing 280 and $70 \mathrm{mM} \mathrm{NaCl}$ were $1.98 \pm 0.09$ and $2.3 \pm 0.2$ respectively, significantly different from the value of $3.7 \pm 0.1$ measured in $14 \mathrm{mM} \mathrm{NaCl}$ ( $\mathrm{n}=12-19 ; p<0.001$ DunnHolland-Wolf test after Kruskal-Wallis test $p=2 \times 10^{-6}$ ). However, although $\mathrm{P}_{\mathrm{Na}} / \mathrm{P}_{\mathrm{Cl}}$ changed with the variation of ionic strength, the TMEM16F wt channel in inside-out patches remained more permeable to $\mathrm{Na}^{+}$than to $\mathrm{Cl}^{-}$. 


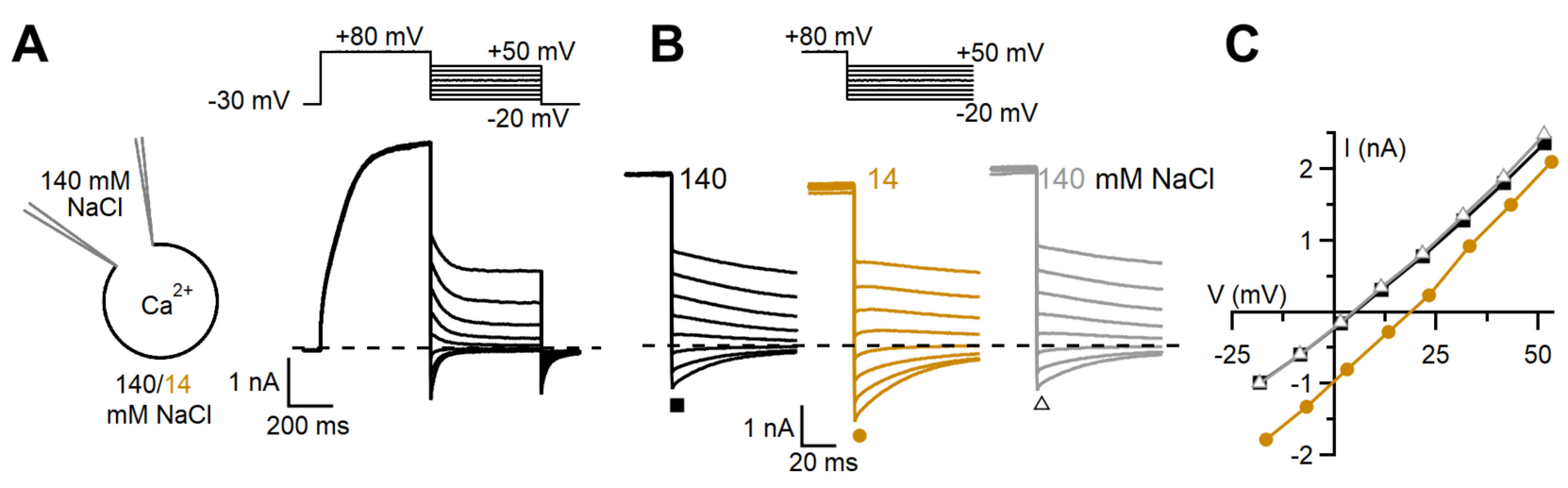

D

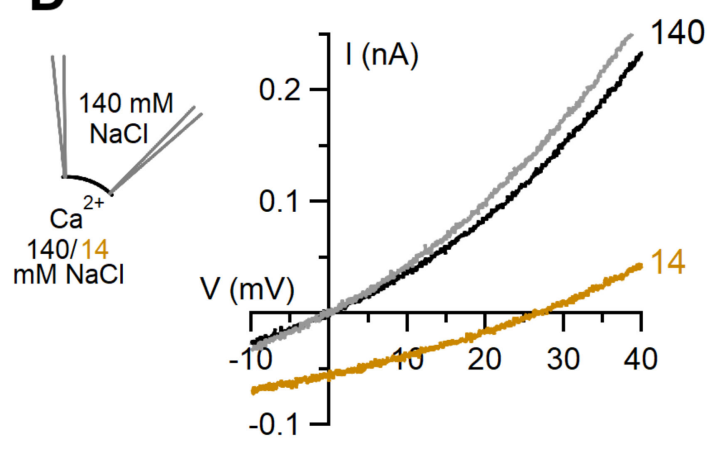

E

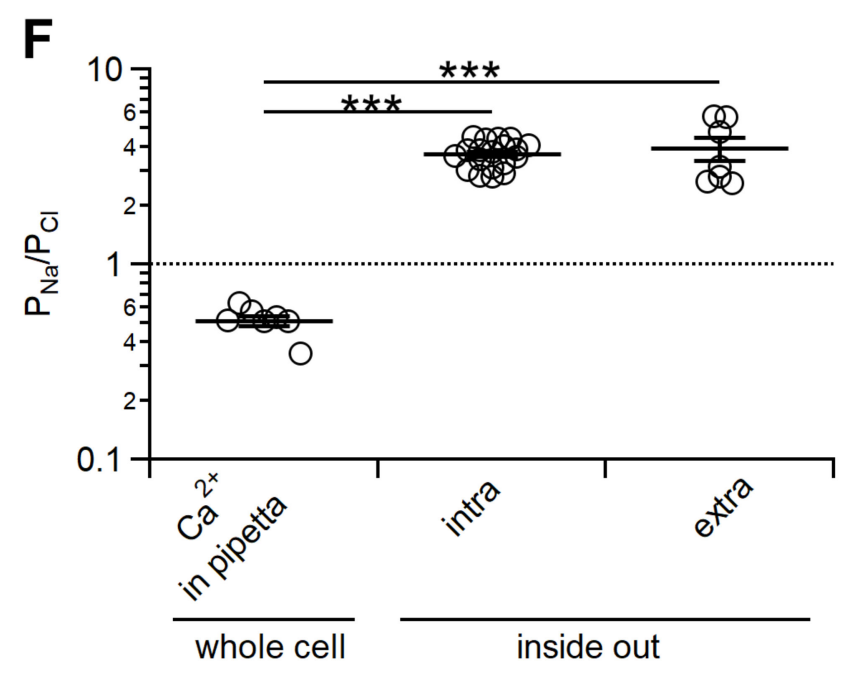

Figure 3. TMEM16F wt ion permeability ratio $\mathrm{P}_{\mathrm{Na}} / \mathrm{P}_{\mathrm{Cl}}$ depends on the recording configuration. (A,B) Representative whole-cell voltage-clamp recordings obtained from representative TMEM16F wt-transfected cells with intracellular solution containing $50 \mu \mathrm{M} \mathrm{Ca}^{2+}$. Voltage protocols are shown at the top of the panels. (B) A cell was first exposed to a control solution containing $140 \mathrm{mM} \mathrm{NaCl}$, then to $14 \mathrm{mM} \mathrm{NaCl}$ and returned to $140 \mathrm{mM} \mathrm{NaCl}$. (C) IV relations measured from tail currents of the cell shown on the left with $140 \mathrm{mM} \mathrm{NaCl}$ (squares), $14 \mathrm{mM} \mathrm{NaCl}$ (circles) and after returning to $140 \mathrm{mM} \mathrm{NaCl}$ (triangles). $(\mathrm{D}, \mathrm{E})$ Inside-out patches expressing TMEM16F wt were exposed to the indicated $\mathrm{NaCl}$ concentrations and the IV relations were determined by voltage ramps from +100 to $-80 \mathrm{mV}$. Only the regions around the reversal potentials are shown. Currents were activated by $100 \mu \mathrm{M} \mathrm{CaCl}_{2}$ and leakage currents measured in $0 \mathrm{Ca}^{2+}$ were subtracted. The pipette solution contained $140 \mathrm{mM} \mathrm{NaCl}$ (D) or $14 \mathrm{mM} \mathrm{NaCl}$ (E). (F) Comparison of $\mathrm{P}_{\mathrm{Na}} / \mathrm{P}_{\mathrm{Cl}}$ calculated with the Goldman-Hodgkin-Katz equation from reversal potentials measured in different recording conditions $\left(\mathrm{n}=7-19 ;{ }^{* * *} p<0.001\right.$ Tukey test after ANOVA, $\left.\mathrm{F}=48.256 p=4.2 \times 10^{-10}\right)$.

Since it has been recently reported that $\mathrm{P}_{\mathrm{Na}} / \mathrm{P}_{\mathrm{Cl}}$ of TMEM16F wt in inside-out patches may depend on $\mathrm{Ca}^{2+}$ concentration [36], we investigated this possibility by reducing $\mathrm{Ca}^{2+}$ from 100 to $13 \mu \mathrm{M}$, a concentration that produced about $10 \%$ of the maximal current at 
$+100 \mathrm{mV}$ (Figure 2E). We found that the value of $\mathrm{P}_{\mathrm{Na}} / \mathrm{P}_{\mathrm{Cl}}$ measured by diluting the bath solution from 140 to $14 \mathrm{mM} \mathrm{NaCl}$ in $13 \mu \mathrm{M} \mathrm{Ca}^{2+}$ (Figure 4C) was not significantly different from that determined in $100 \mu \mathrm{M} \mathrm{Ca}^{2+}$ (Figure $4 \mathrm{D}$ ), indicating that $\mathrm{P}_{\mathrm{Na}} / \mathrm{P}_{\mathrm{Cl}}$ permeability of TMEM16F wt in inside-out patches did not change with $\mathrm{Ca}^{2+}$ concentration. Furthermore, in patches with a slow rundown, we repeated measurements of the reversal potential at different times after patch excision and found similar values, indicating that the ion selectivity did not change with time.
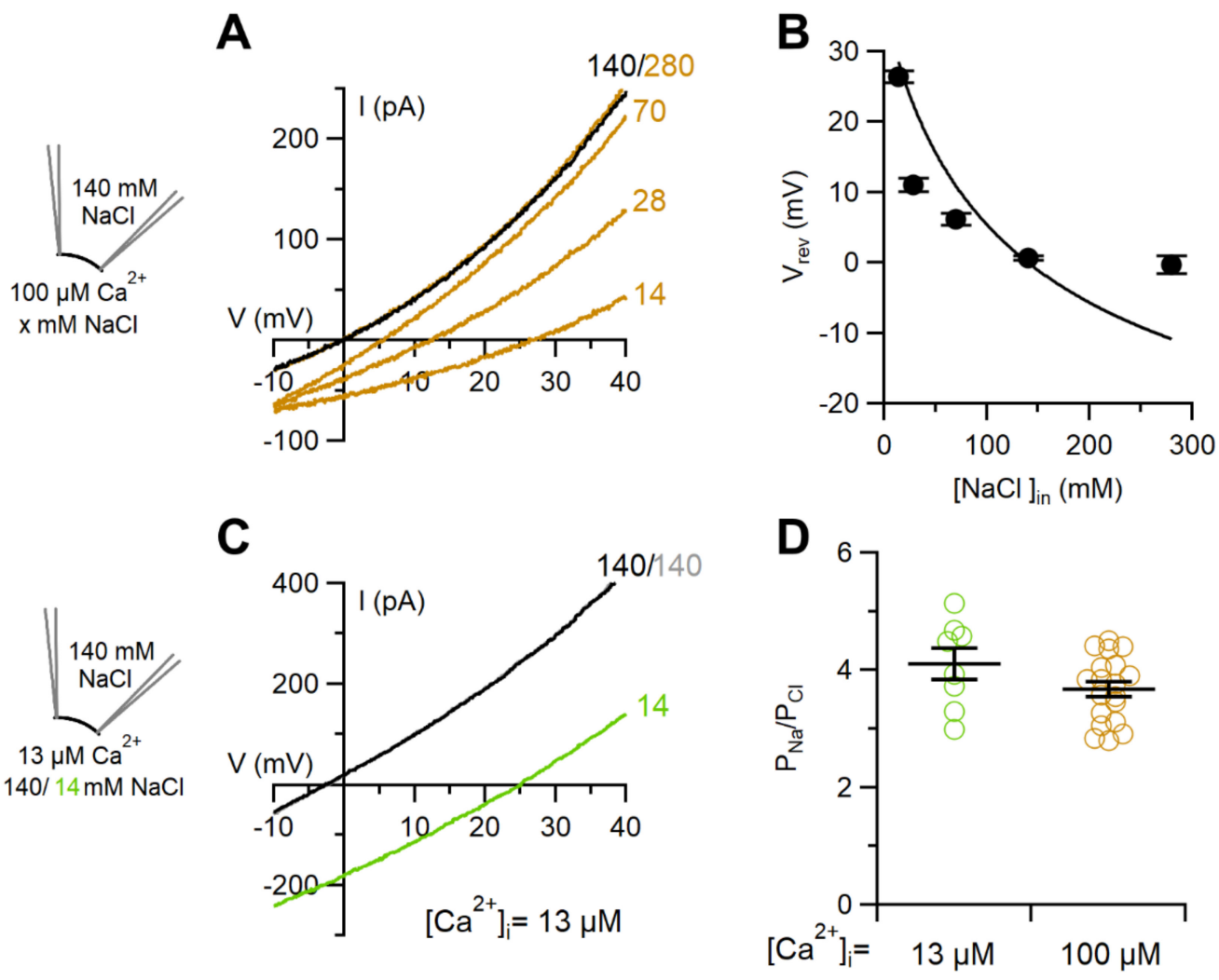

Figure 4. TMEM16F wt ion permeability ratio $\mathrm{P}_{\mathrm{Na}} / \mathrm{P}_{\mathrm{Cl}}$ in excised inside-out patches depends on ionic strength but not on intracellular $\mathrm{Ca}^{2+}$ concentration. (A) An inside-out patch expressing TMEM16F wt was exposed to the indicated cytoplasmatic $\mathrm{NaCl}$ concentrations (in $\mathrm{mM}$ ) and the IV relations were determined by a voltage ramp from +100 to $-80 \mathrm{mV}$. Only the regions around the reversal potentials are shown. The current was activated by $100 \mu \mathrm{M} \mathrm{CaCl}_{2}$. Leakage currents measured in 0 $\mathrm{Ca}^{2+}$ were subtracted. (B) Average reversal potentials $\left(\mathrm{V}_{\text {rev }}\right)$ corrected for liquid junction potentials were plotted versus $\mathrm{NaCl}$ concentrations $(\mathrm{n}=11-19)$. The continuous line was calculated according to the Goldman-Hodgkin-Katz equation with $\mathrm{P}_{\mathrm{Na}} / \mathrm{P}_{\mathrm{Cl}}=3.7$. (C) An inside-out patch expressing TMEM16F was exposed to 140 or $14 \mathrm{mM}$ cytoplasmatic $\mathrm{NaCl}$ and the IV relation was determined by a voltage ramp from +100 to $-80 \mathrm{mV}$. The current was activated by $13 \mu \mathrm{M} \mathrm{CaCl}_{2}$. (D) Comparison of $\mathrm{P}_{\mathrm{Na}} / \mathrm{P}_{\mathrm{Cl}}$ calculated with the Goldman-Hodgkin-Katz equation from reversal potentials measured with the indicated $\mathrm{Ca}^{2+}$ concentration $(\mathrm{n}=8-19, p=0.19$ unpaired $t$-test).

To further investigate the permeability of TMEM16F wt to different cations and anions, we replaced $\mathrm{NaCl}$ in the bathing solution with NMDG-Cl, NaMeS or NaSCN and compared the shift of the reversal potentials by taking into account that ion replacements occurred at the opposite side of the membrane in the two patch-clamp configurations (Figure 5A,B). We found that the large cation $\mathrm{NMDG}^{+}$was poorly permeant through the TMEM16F wt pore without any significant difference between whole-cell and inside-out recordings, indeed the change of reversal potential was $-2.9 \pm 1 \mathrm{mV}$ in whole cell and $4.3 \pm 0.7 \mathrm{mV}$ in inside-out patches (Figure $5 \mathrm{C}, \mathrm{n}=4-5, p=0.29$, unpaired $t$-test). The large anion $\mathrm{MeS}^{-}$ was also permeant, although at different extents depending on the recording method. 
Indeed, substitution of $\mathrm{NaCl}$ with $\mathrm{NaMeS}$ in whole-cell shifted the reversal potential of $21.5 \pm 0.5 \mathrm{mV}(\mathrm{n}=3)$, indicating that $\mathrm{MeS}^{-}$was much less permeant than $\mathrm{Cl}^{-}$, whereas in inside-out the change was only $-1.6 \pm 0.7 \mathrm{mV}(\mathrm{n}=14)$ showing a very small difference between $\mathrm{MeS}^{-}$and $\mathrm{Cl}^{-}$permeability (Figure $5 \mathrm{C}$ ). $\mathrm{SCN}^{-}$showed a higher permeability than $\mathrm{Cl}^{-}$in both recording conditions, although it was found to be more permeant in the inside-out configuration (Figure 5C). Using the inside-out configuration, we also tested the permeation of several other anions finding the following permeability sequence for TMEM16F wt: $\mathrm{SCN}^{-}>\mathrm{I}^{-}>\mathrm{NO}_{3}{ }^{-}>\mathrm{Br}^{-}>\mathrm{Cl}^{-}$(Figure S4).

A
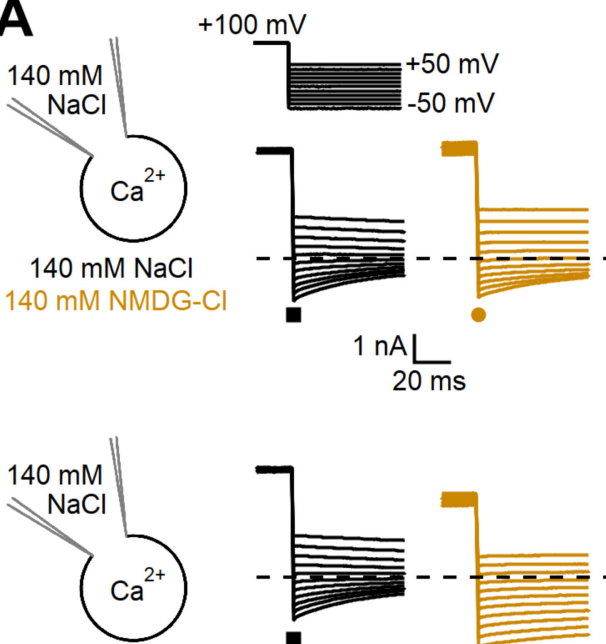

$140 \mathrm{mM} \mathrm{NaCl}$ $140 \mathrm{mM}$ NaMeS
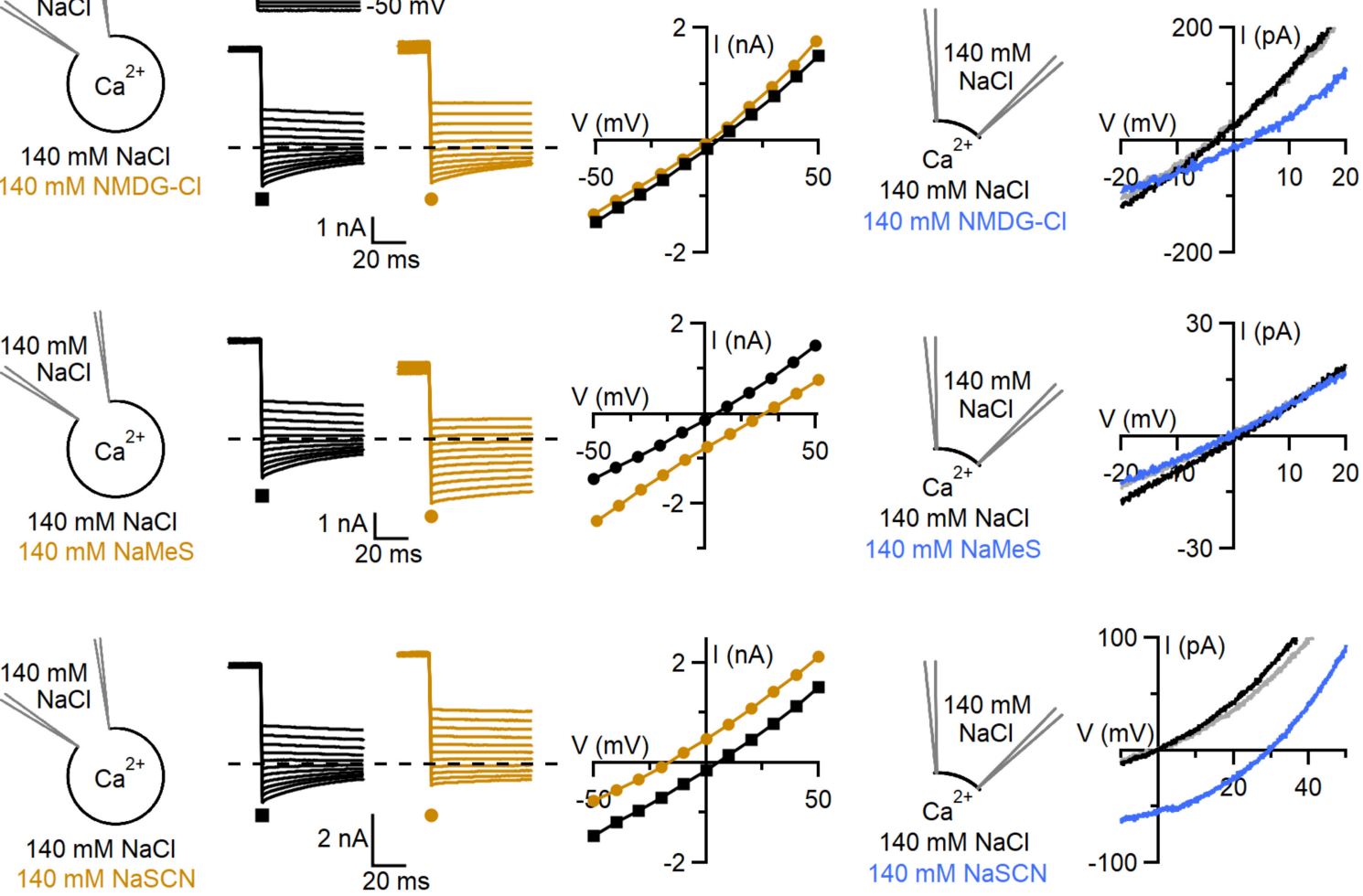

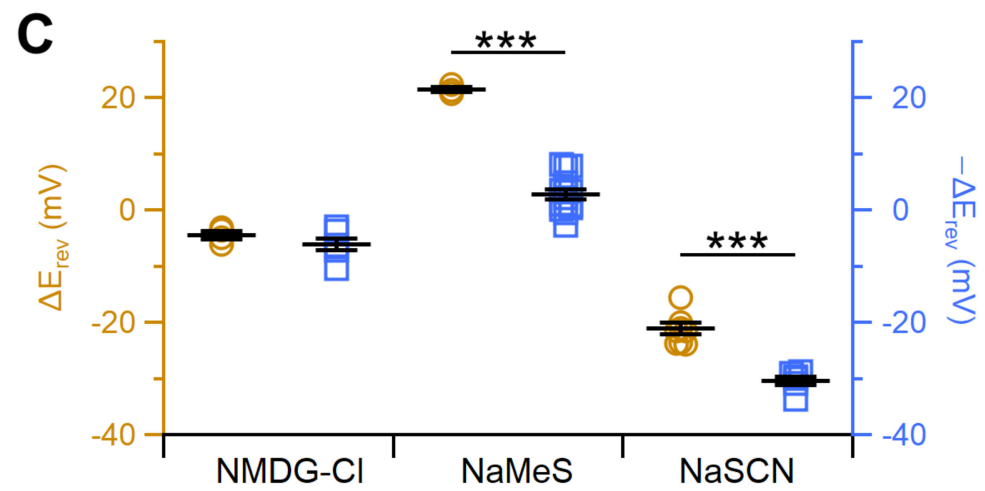

Figure 5. TMEM16F wt ion permeability depends on the recording configuration. (A) Representative whole-cell voltageclamp recordings obtained from TMEM16F wt-transfected cells with intracellular solution containing $100 \mu \mathrm{M} \mathrm{CaCl}$. Each cell was exposed to a control solution containing $140 \mathrm{mM} \mathrm{NaCl}$ (black traces) or other salts as indicated (brown traces). On 
the right, IV relations measured from tail currents of the cells on the left with $140 \mathrm{mM} \mathrm{NaCl}$ (black squares) or $140 \mathrm{mM}$ of the indicated salt (brown circles). (B) An inside-out patch expressing TMEM16F wt was exposed to bath solutions containing $140 \mathrm{mM} \mathrm{NaCl}$ (black traces) or the indicated salts (blue traces). The grey traces represent the wash out with $\mathrm{NaCl}$. IV relations were determined by voltage ramps from +100 to $-80 \mathrm{mV}$. Only the regions around the reversal potentials are shown. Currents were activated by $1 \mathrm{mM} \mathrm{CaCl}_{2}$ and leakage currents measured in $0 \mathrm{Ca}^{2+}$ were subtracted. (C) Comparison of the shift of reversal potentials obtained in different recording configurations for the indicated ionic solutions $\left({ }^{* * *} p<0.001\right.$, for NaMeS: $p=9.7 \times 10^{-12}$ and for NaSCN: $p=8 \times 10^{-6}$, unpaired $t$-test).

\subsection{Comparison between Ion Selectivity of TMEM16F Q559K in Whole-Cell and Inside-Out Configurations}

TMEM16F Q559K is considered to be a pore mutant because it altered ion selectivity in inside-out patches by reducing the selectivity of the channel to $\mathrm{Na}^{+}$with respect to $\mathrm{Cl}^{-}$[23]. We repeated the same experiments in excised patches and investigated whether a change of selectivity was present also in whole-cell recordings.

First, we characterised the activation by $\mathrm{Ca}^{2+}$ of the Q559K mutant that showed, as the TMEM16F wt, a slow increase of current with time in whole-cell and a fast activation in the inside-out configurations (Figure S5). The dose-response curve in inside-out patches showed a lower apparent $\mathrm{Ca}^{2+}$ sensitivity for Q559K compared to wt.

For ion selectivity, we confirmed the previous data in inside-out patches showing that $\mathrm{Q} 559 \mathrm{~K}$ was less permeable to $\mathrm{Na}^{+}$than TMEM16F wt. In $1 \mathrm{mM} \mathrm{Ca}^{2+}, \mathrm{P}_{\mathrm{Na}} / \mathrm{P}_{\mathrm{Cl}}$ was $0.71 \pm 0.01(\mathrm{n}=18)$ in Q559K (Figure 6D,F) to be compared with the value of $3.7 \pm 0.1$ $(\mathrm{n}=19)$ in TMEM16F wt. Moreover, reduction from 140 to $14 \mathrm{mM} \mathrm{NaCl}$ in the pipette solutions bathing the extracellular side of the membrane did not significantly modify $\mathrm{P}_{\mathrm{Na}} / \mathrm{P}_{\mathrm{Cl}}$ that had a value of $0.62 \pm 0.04(\mathrm{n}=5)$, indicating that the pore of the Q559K mutant was not asymmetric, similarly to the wt pore (Figure $6 \mathrm{E}, \mathrm{F}$ ). In addition, we also confirmed that ion selectivity of Q559K depends on intracellular $\mathrm{Ca}^{2+}$ concentration as previously reported [36]. Indeed, we found that activation of the Q559K channel by $13 \mu \mathrm{M} \mathrm{Ca}^{2+}$ produced a significantly higher $\mathrm{P}_{\mathrm{Na}} / \mathrm{P}_{\mathrm{Cl}}$ of $1.9 \pm 0.1$ compared to $0.71 \pm 0.01$ measured in $1 \mathrm{mM} \mathrm{Ca}^{2+}$ (Figure S6), although we did not measure any change of $\mathrm{P}_{\mathrm{Na}} / \mathrm{P}_{\mathrm{Cl}}$ with $\mathrm{Ca}^{2+}$ concentration in the TMEM16F wt channel (Figure 4D).

Whole-cell recordings showed that the value of $\mathrm{P}_{\mathrm{Na}} / \mathrm{P}_{\mathrm{Cl}}$ for the Q559K mutant activated by $300 \mu \mathrm{M} \mathrm{Ca}^{2+}$ was $0.41 \pm 0.03(\mathrm{n}=8$, Figure $6 \mathrm{~A}-\mathrm{C}, \mathrm{F})$, significantly different from $0.62 \pm 0.04$ measured for Q559K in inside-out, but not significantly different from $0.52 \pm 0.03(n=7)$ for the wt channel (Figure $6 \mathrm{~F}$ ), showing that the mutation did not modify selectivity in the whole-cell configuration. 


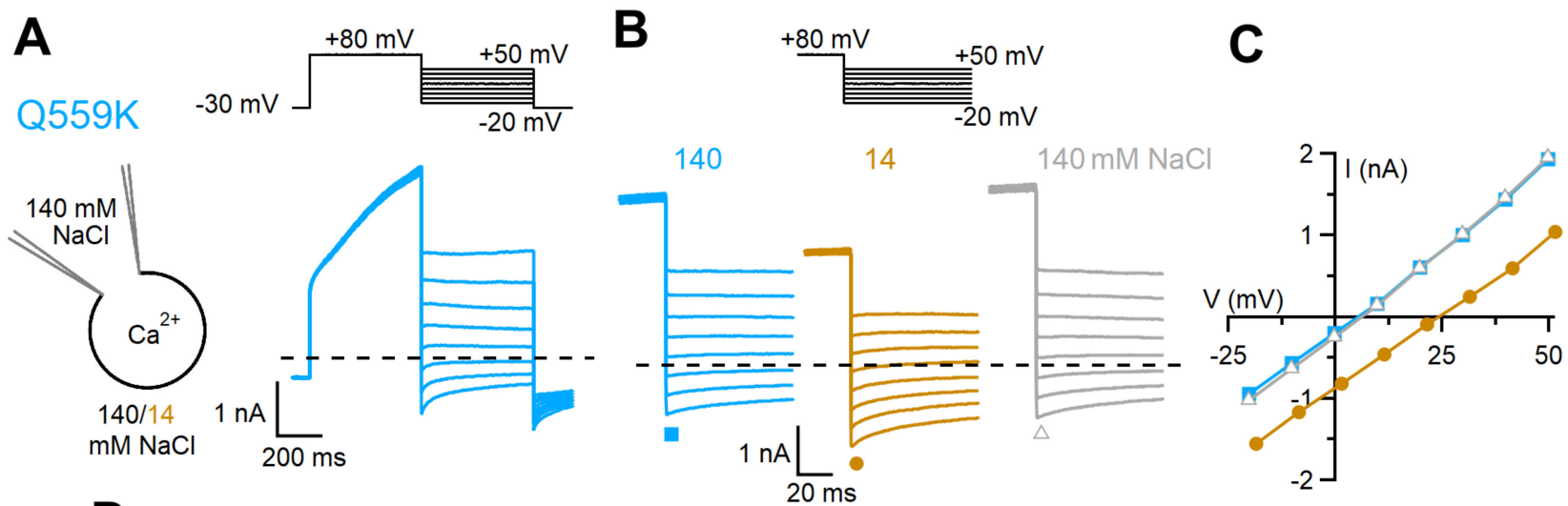

D

E
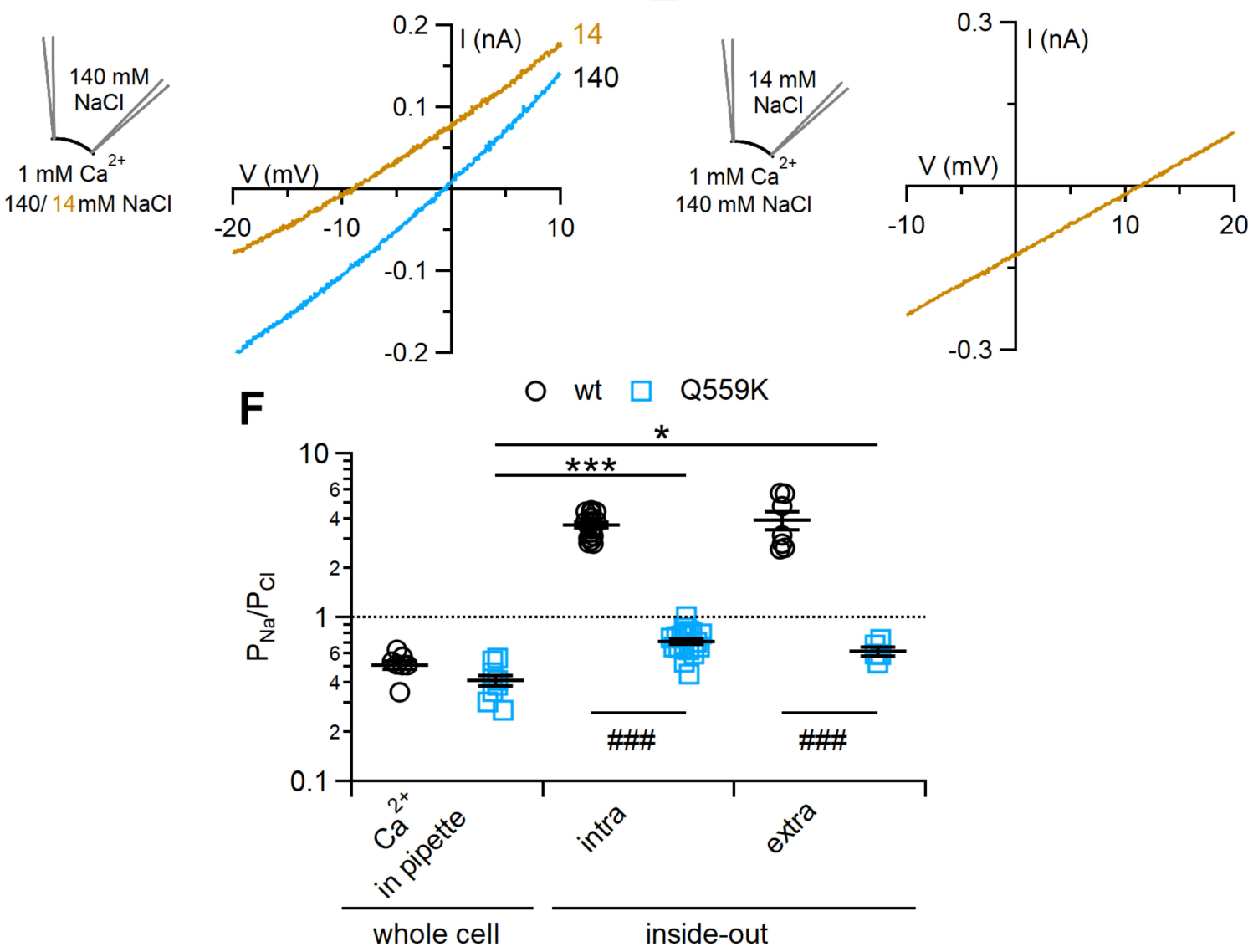

Figure 6. Q559K ion permeability ratio $\mathrm{P}_{\mathrm{Na}} / \mathrm{P}_{\mathrm{Cl}}$ depends on the recording configuration. (A,B) Representative whole-cell voltage-clamp recordings obtained from TMEM16F Q559K mutant-transfected cells with intracellular solution containing $300 \mu \mathrm{M} \mathrm{Ca}^{2+}$. Voltage protocols are shown at the top of the panels. (B) A cell was exposed to a control solution containing $140 \mathrm{mM} \mathrm{NaCl}$, then to $14 \mathrm{mM} \mathrm{NaCl}$, followed by wash out with $140 \mathrm{mM} \mathrm{NaCl}$. (C) IV relations measured from tail currents of the cell shown on the left with $140 \mathrm{mM} \mathrm{NaCl}$ (squares), $14 \mathrm{mM} \mathrm{NaCl}$ (circles) and after wash out (triangles). (D,E) Inside-out patches expressing TMEM16F were exposed to the indicated $\mathrm{NaCl}$ concentrations, and the IV relations were determined by voltage ramps from +100 to $-80 \mathrm{mV}$. Only the regions around the reversal potentials are shown. Currents were activated by $1 \mathrm{mM} \mathrm{CaCl}_{2}$ and leakage currents measured in $0 \mathrm{Ca}^{2+}$ were subtracted. The pipette solution contained $140 \mathrm{mM} \mathrm{NaCl}(\mathrm{C})$ or $14 \mathrm{mM} \mathrm{NaCl}$ (D). (F) Comparison of $\mathrm{P}_{\mathrm{Na}} / \mathrm{P}_{\mathrm{Cl}}$ in different recording conditions for Q559K and wt $\left(\mathrm{n}=5-19 ;{ }^{* * *} p<0.001\right.$, ${ }^{*} p<0.05$ Tukey test after ANOVA, $\mathrm{F}=18.271, p=8.36 \times 10^{-6}$; \#\#\# $p<0.001$, unpaired $t$-test).

\subsection{Ion Selectivity and Scramblase Activity}

As TMEM16F functions both as $\mathrm{Ca}^{2+}$-activated ion channel and as $\mathrm{Ca}^{2+}$-activated lipid scramblase, we also tested if ion selectivity depends on scramblase activity by using 
two mutants that differently affect the scrambling activity, the scrambling-deficient D703R mutant and the constitutive scrambling Y563A mutant [40]. Figure 7A shows currents activated by the exposure of the cytoplasmic side of inside-out excised patches to $1 \mathrm{mM}$ $\mathrm{Ca}^{2+}$ at the holding potential of $+60 \mathrm{mV}$. Currents were rapidly activated by $\mathrm{Ca}^{2+}$ in the two mutants with kinetics similar to the wt channel. To determine if scramblase activity modifies the $\mathrm{P}_{\mathrm{Na}} / \mathrm{P}_{\mathrm{Cl}}$ permeability, we measured reversal potentials upon reduction of bath $\mathrm{NaCl}$ from 140 to $14 \mathrm{mM}$ (Figure 7B). The positive shifts of reversal potentials, $38 \pm 3 \mathrm{mV}$ $(\mathrm{n}=3)$ for D703R and $26 \pm 2 \mathrm{mV}(\mathrm{n}=6)$ for Y563A, indicate that both mutants measured in the inside-out configuration were more selective for $\mathrm{Na}^{+}$than for $\mathrm{Cl}^{-}$similarly to wt $(25.5 \pm 0.6 \mathrm{mV}, \mathrm{n}=19)$. Furthermore, $\mathrm{P}_{\mathrm{Na}} / \mathrm{P}_{\mathrm{Cl}}(3.9 \pm 0.4, \mathrm{n}=6)$ for the constitutive scramblase mutant Y563A was not significantly different from the wt value, whereas $\mathrm{P}_{\mathrm{Na}} / \mathrm{P}_{\mathrm{Cl}}$ for the scrambling-deficient D703R mutant $(9 \pm 2, \mathrm{n}=3)$ was significantly higher than the wt value $\left(3.7 \pm 0.1\right.$, Figure 7F), indicating an even higher selectivity for $\mathrm{Na}^{+}$than for $\mathrm{Cl}^{-}$of D703R compared to wt.

Furthermore, we extended the comparison of permeabilities to other ions by substituting $\mathrm{NaCl}$ in the bathing solution with NMDG-Cl, NaMeS or NaSCN (Figure 7C-E,G). All three channels were permeable to the large cation $\mathrm{NMDG}^{+}$and to the large anion $\mathrm{MeS}^{-}$, with the scrambling-deficient D703R mutant more permeable to these ions than the other two channels. $\mathrm{SCN}^{-}$was equally permeant in the three channels. Thus, data obtained with the constitutive scrambling Y563A mutant were not significantly different from the $\mathrm{wt}$, while the scrambling-deficient D703R mutant showed some difference (Figure 7G). 

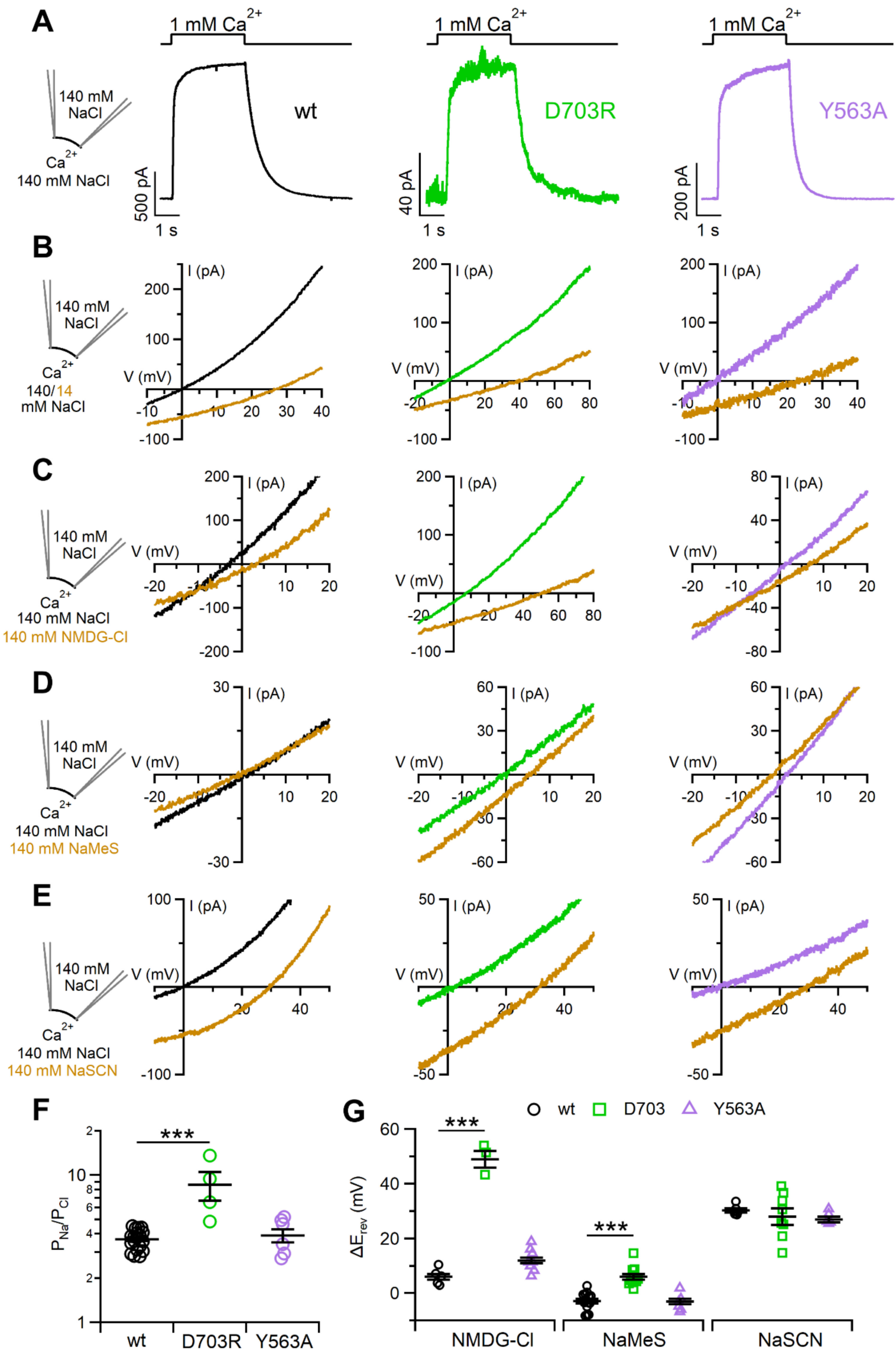

Figure 7. Ion permeability of the TMEM16F wt, D703R and Y563A mutants. (A) Inside-out excised membrane patches 
expressing TMEM16F wt or the indicated mutant were stimulated with a solution containing $1 \mathrm{mM} \mathrm{Ca}^{2+}$ at the time indicated in the upper traces. The holding potential was $+60 \mathrm{mV}$. Patches were exposed to $140 \mathrm{mM} \mathrm{NaCl}$ and $(\mathbf{B}) 14 \mathrm{mM}$ $\mathrm{NaCl},(\mathbf{C}) 140 \mathrm{mM}$ NMDG-Cl, (D) $140 \mathrm{mM}$ NaMeS or (E) $140 \mathrm{mM}$ NaSCN. IV relations were determined by voltage ramps from +100 to $-80 \mathrm{mV}$. Only the regions around reversal potentials are shown. Leakage currents measured in $0 \mathrm{Ca}^{2+} \mathrm{were}^{2}$ subtracted. (F) Comparison of $\mathrm{P}_{\mathrm{Na}} / \mathrm{P}_{\mathrm{Cl}}$ for TMEM16F wt and the indicated mutants $(\mathrm{n}=3-19$, *** $p<0.001$, Dunnett test after ANOVA $\left.\mathrm{F}=19.303, p=7.26 \times 10^{-6}\right)$. (G) Comparison of the shift of reversal potentials after the replacement of $140 \mathrm{mM} \mathrm{NaCl}$ with $140 \mathrm{mM}$ NMDG-Cl, NaMeS or NaSCN for TMEM16F wt and the indicated mutants (for NMDG-Cl: ${ }^{* * *} p<0.001$, Dunnett test after ANOVA F $=30.569, p=7.79 \times 10^{-6}$; for NaMeS: ${ }^{* * *} p<0.001$, Dunnett test after ANOVA $\mathrm{F}=26.3, p=3.86 \times 10^{-7}$; for NaSCN: ANOVA, $\left.\mathrm{F}=1.499, p=0.25\right)$.

\section{Discussion}

Our results provide a detailed side-by-side comparison of the electrophysiological properties of TMEM16F wt and Q559K recorded in the whole-cell and inside-out modes. We measured the important differences between several features of the TMEM16F-mediated currents depending on the recording configuration. Indeed, in inside-out recordings, the TMEM16F wt channel was rapidly activated by $\mathrm{Ca}^{2+}$ and had a higher permeability to $\mathrm{Na}^{+}$ than to $\mathrm{Cl}^{-}$, while in the whole-cell configuration the channel was activated by $\mathrm{Ca}^{2+}$ only after a delay of several minutes and was slightly more permeable to $\mathrm{Cl}^{-}$than to $\mathrm{Na}^{+}$.

\subsection{Calcium Activation}

Our data confirm that the kinetics of activation by $\mathrm{Ca}^{2+}$ strongly depend on the recording configuration. Indeed, in the inside-out configuration, both TMEM16F wt and Q559K currents were rapidly activated within a few $\mathrm{ms}$ from $\mathrm{Ca}^{2+}$ application (Figure 1D) in agreement with previous results $[23,35,36]$. Moreover, the amplitude of TMEM16F $\mathrm{Ca}^{2+}$-activated currents in inside-out underwent a progressive rundown as previously observed by Ye et al. [41], who showed that the rundown was due to depletion of phosphatidylinositol- $(4,5)$-bisphosphate $\left(\mathrm{PIP}_{2}\right)$ in excised patches. Both the fast $\mathrm{Ca}^{2+}$ activation and the rundown in inside-out patches resemble those measured in TMEM16A [42] and TMEM16B $[8,9]$.

In contrast, the TMEM16 $\mathrm{Fa}^{2+}$-activated current in whole-cell recordings slowly and progressively developed after a delay of some minutes following membrane breaking and did not show rundown. The time necessary to obtain the maximal current was about 2 min with $100 \mu \mathrm{M} \mathrm{Ca}^{2+}$ in the patch pipette and increased to about 20 min with a reduction in intracellular $\mathrm{Ca}^{2+}$ to $3.8 \mu \mathrm{M}$ (Figure 1B,C). This slow activation is in agreement with the results from previous studies for TMEM16F [27,43], while it differs from the fast kinetics of activation by $\mathrm{Ca}^{2+}$ measured in whole-cell mode for TMEM16A and TMEM16B $[5,7,8,38]$. For TMEM16E, which acts both as an ion channel and scramblase similarly to TMEM16F, whole-cell currents were rapidly activated by intracellular $\mathrm{Ca}^{2+}$ in a study by Di Zanni et al. [44], while another study reported current activation after a delay of several minutes [45]. For TMEM16F, activation kinetics by $\mathrm{Ca}^{2+}$ in whole-cell mode have been shown to be modified by the actin cytoskeleton, as molecules that interfere with actin polymerisation accelerated TMEM16F activation [46].

Our dose-response experiments showed that TMEM16F wt requires several $\mu \mathrm{M}$ of $\mathrm{Ca}^{2+}$ to be activated and that the Q559K mutant has an even lower $\mathrm{Ca}^{2+}$ sensitivity, in agreement with the previous results [34,35]. The low sensitivity of the Q559K mutant to $\mathrm{Ca}^{2+}$ is likely to explain why a previous attempt by Scudieri et al. [47] to measure Q559K ion selectivity in whole-cell did not produce any current as they were using a $\mathrm{Ca}^{2+}$ concentration of $20 \mu \mathrm{M}$ that was sufficient to activate the TMEM16F wt current but probably too low to measure a current in the mutant.

The low $\mathrm{Ca}^{2+}$ sensitivity of TMEM16F suggests that its activation requires the presence of local nano- or micro-domains where $\mathrm{Ca}^{2+}$ can reach elevated local concentrations. A similar organisation was reported also for the activation of $\mathrm{Ca}^{2+}$-activated $\mathrm{K}^{+}$channels [48] and is important for the activation of TMEM16B in the cilia of olfactory sensory neurons [12,49]. 


\subsection{Ion Selectivity}

Measurements of the ion selectivity of TMEM16F wt gave rise to contrasting results in previous reports and our side-by-side comparison indicates that several discrepancies are due to the different recording configurations used. In our experiments, TMEM16F wt measured in the presence of a high $\mathrm{Ca}^{2+}$ concentration had a slightly higher permeability to $\mathrm{Cl}^{-}$than to $\mathrm{Na}^{+}$in whole-cell, with a permeability ratio $\mathrm{P}_{\mathrm{Na}} / \mathrm{P}_{\mathrm{Cl}}$ of 0.52 , while an opposite higher permeability to $\mathrm{Na}^{+}$than to $\mathrm{Cl}^{-}$, with $\mathrm{P}_{\mathrm{Na}} / \mathrm{P}_{\mathrm{Cl}}$ of 3.7 , was measured in the inside-out configuration (Figure 3). We also tested the possibility that the different permeabilities could be due to an asymmetric channel pore or to a change of ionic strength, because $\mathrm{NaCl}$ concentration was reduced at different sides of the channel in the two patch-clamp configurations (extracellular in whole-cell and intracellular, in inside-out). Reduction of the $\mathrm{NaCl}$ concentration from 140 to $14 \mathrm{mM}$ at the extracellular side of the membrane produced a $\mathrm{P}_{\mathrm{Na}} / \mathrm{P}_{\mathrm{Cl}}$ of 3.9 similar to the value of 3.7 obtained by varying $\mathrm{NaCl}$ at the intracellular side, showing that also in these experimental conditions $\mathrm{Na}^{+}$was more permeant than $\mathrm{Cl}^{-}$in the inside-out mode. Thus, the significant difference between $\mathrm{P}_{\mathrm{Na}} / \mathrm{P}_{\mathrm{Cl}}$ measured in whole-cell and in the inside-out configuration was not due to an asymmetric channel pore or to a change of ionic strength (Figure 3E). Moreover, as a previous study [36] reported that permeability may change with $\mathrm{Ca}^{2+}$ concentration, we also compared $\mathrm{P}_{\mathrm{Na}} / \mathrm{P}_{\mathrm{Cl}}$ when TMEM16F wt was activated by a lower $\mathrm{Ca}^{2+}$ concentration and found that the value measured at $13 \mu \mathrm{M}(4.1)$ was not different from that measured at $100 \mu \mathrm{M}$ $\mathrm{Ca}^{2+}(3.7$, Figure 4D).

TMEM16F wt is permeable to several anions, including the large anion $\mathrm{MeS}^{-}$, and to many cations, including the large cation $\mathrm{NMDG}^{+}$(Figure 5). The anion permeability sequence in inside-out was $\mathrm{SCN}^{-}>\mathrm{I}^{-}>\mathrm{NO}_{3}{ }^{-}>\mathrm{Br}^{-}>\mathrm{Cl}^{-}$(Figure S1) in agreement with other studies in inside out and whole-cell recordings $[26,27,35]$ and is similar to that measured for TMEM16A and TMEM16B [7-9,50]. These data show that anions with lower dehydration energy are more permeant compared to those with higher dehydration energy and suggest a conserved mechanism of anion permeation among these channels.

In agreement with a previous report [23], we found that cation selectivity in insideout patches was reduced by the Q559K pore mutation. In our experiments, the value of $\mathrm{P}_{\mathrm{Na}} / \mathrm{P}_{\mathrm{Cl}}$ was 0.71 (or 0.62 ) when $\mathrm{NaCl}$ concentration was reduced from 140 to $14 \mathrm{mM}$ at the intracellular (or extracellular) side of the patch membrane and channels were activated by high $\mathrm{Ca}^{2+}$ concentrations. $\mathrm{P}_{\mathrm{Na}} / \mathrm{P}_{\mathrm{Cl}}$ increased to 1.9 when TMEM16F Q559K was activated by $13 \mu \mathrm{M} \mathrm{Ca}^{2+}$ (Figure S3), in agreement with the trend of permeability change with $\mathrm{Ca}^{2+}$ concentration previously reported [36].

When the permeability ratio was measured in whole-cell, $\mathrm{P}_{\mathrm{Na}} / \mathrm{P}_{\mathrm{Cl}}$ of $\mathrm{Q} 559 \mathrm{~K}$ was 0.41 , slightly lower than the value of 0.71 measured in inside-out. Surprisingly, $\mathrm{P}_{\mathrm{Na}} / \mathrm{P}_{\mathrm{Cl}}$ of the $\mathrm{Q} 559 \mathrm{~K}$ pore mutant (0.41) measured in whole-cell was not different from the value of TMEM16F wt (0.52), showing that the mutation did not modify selectivity in the whole-cell configuration.

We also investigated whether the $\mathrm{Ca}^{2+}$-activated scramblase activity of TMEM16F could play a role in ion selectivity. Indeed, previous work [43] identified a protein domain required for scrambling of TMEM16F that is sufficient to produce scramblase activity also in TMEM16A, and Jiang et al. [51] showed that the TMEM16A V543S mutation conferred scramblase activity to TMEM16A. In both studies, TMEM16A (that is anion selective) became more cation selective after phospholipid scrambling occurred, showing that ion selectivity was influenced by scramblase activity. In another study (Malvezzi et al., 2013), ion channel properties of afTMEM16 (TMEM16 from the fungus Aspergillus fumigatus) reconstituted in lipid bilayers were reported to strongly depend on the lipid composition, suggesting that different lipid environments generated by the scramblase activity may affect the properties of the TMEM16F pore. Le et al. [40] identified residues that play important roles in scramblase activity and showed that the TMEM16F Y563A mutant Fproduced a constitutive scrambling activity while the D703R mutant abolished scrambling activity. They also compared ion selectivity between Y563A and wt (but not for D603R) showing that $\mathrm{P}_{\mathrm{Na}} / \mathrm{P}_{\mathrm{Cl}}$ increased in the mutant (Figure S4E,F in [40]). In our experiments, $\mathrm{P}_{\mathrm{Na}} / \mathrm{P}_{\mathrm{Cl}}$ for the constitutive scramblase Y563A mutant was 3.9 similar to 3.7 measured in the 
wt, while it increased to 9 for the scrambling-deficient D703R mutant, indicating that a higher selectivity for $\mathrm{Na}^{+}$than for $\mathrm{Cl}^{-}$was measured in the absence of scramblase activity (Figure 7). We also compared the selectivity to other anions and cations and confirmed the absence of differences between Y563A and wt, while the large cation $\mathrm{NMDG}^{+}$and anion $\mathrm{MeS}^{-}$were more permeant in the scrambling-deficient D703R mutant than in wt. These results do not support the possibility that TMEM16F could become more cation selective after lipid scrambling as was shown for TMEM16A [43,51].

One possible explanation of the differences we measured in the two configurations could be the different tension of the membrane in inside-out with respect to whole-cell configuration [52]. Indeed, recent studies showed that many ion channels are modulated by mechanical forces applied to lipid bilayer $[53,54]$.

It is also tempting to speculate that the different data obtained using the two recording configurations could be due to a still unidentified factor that binds TMEM16F in the wholecell configuration and is lost in excised patches. Interestingly, calmodulin has been shown to be able to modulate the $\mathrm{Ca}^{2+}$ sensitivity [55] and permeability [56] of TMEM16A, even if these results were challenged [57]. Several other possible binding partners of TMEM16 proteins have been reported. Huang et al. [58] showed that TMEM16C binds the $\mathrm{Na}^{+}-$ activated $\mathrm{K}^{+}$channel Slack, increasing the single-channel activity and sodium sensitivity of Slack channels; structural data by Pan et al. [59] revealed that TMC1 channels share a common architecture with the TMEM16 channel, raising the possibility that some TMCbinding proteins could also bind TMEM16F; Avalos-Prado et al. [60] reported that KCNE1 is an auxiliary subunit of TMEM16A. However, also several other modulators including cholesterol, fatty acids, phosphorylation, have been shown to regulate the activity of some TMEM16 family members $[4,61]$.

\subsection{Conclusions}

In summary, our data provide a clear demonstration that the time dependence of $\mathrm{Ca}^{2+}$ activation and the ion selectivity of TMEM16F depend on the recording configuration, contributing to a clarification of the previous conflicting data.

\section{Materials and Methods}

\subsection{Cell Culture and Transfection}

HEK-293 cells were grown in medium composed of DMEM (Gibco, Milano, Italy) supplemented with 10\% foetal bovine serum (Sigma, Milano, Italy), $100 \mathrm{IU} / \mathrm{mL}$ penicillin and $100 \mu \mathrm{g} / \mathrm{mL}$ streptomycin (Sigma, Milano, Italy) at $37^{\circ} \mathrm{C}$ in a humidified atmosphere of $5 \% \mathrm{CO}_{2}$.

pEGFP-N1 plasmids containing the cDNA of mouse TMEM16F wt (version 1 as in [46]) or Q559K mutant were provided by Professor Lily Jan (UCSF, San Francisco, CA, USA). pEGFP-N1 plasmids containing the cDNA of D703R and Y563A mutants were provided by Professor Huanghe Yang (Duke University, Durham, NC, USA). HEK-293 cells were transfected with $2 \mu \mathrm{g}$ TMEM16F cDNA using the transfection reagent XtremeGENE (Roche Diagnostic, Milano, Italy). Twenty-four hours after transfection, the cells were sub-cultured in 35-mm Petri dishes at a lower density. Electrophysiological recordings were performed between 48 and $72 \mathrm{~h}$ after transfection.

\subsection{Electrophysiological Recordings}

TMEM16F-transfected HEK-293 cells were identified by EGFP fluorescence using an Olympus IX70 microscope (Olympus, Tokyo, Japan) equipped with the appropriate filter. TMEM16F currents were recorded in whole-cell or inside-out configurations in voltageclamp mode using an Axopatch 1-D amplifier controlled by Clampex 9.2 via Digidata 1322A (Axon Instruments, San Jose, CA, USA). The data were acquired at a rate of $10 \mathrm{kHz}$, and the signals were low-pass filtered at $5 \mathrm{kHz}$. Patch electrodes were made of borosilicate glass (WPI, Friedberg, Germany) and pulled with a PP-830 micropipette puller (Narishige, 
Tokyo, Japan). Pulled patch electrodes had a resistance of 2-3 $\mathrm{M} \Omega$ for whole-cell recordings and $0.5-1 \mathrm{M} \Omega$ for the inside-out configuration when filled with pipette solution.

The bath was ground with a $3 \mathrm{M} \mathrm{KCl}$ agar bridge connected with an $\mathrm{Ag} / \mathrm{AgCl}$ reference electrode. In experiments with pipette solution without $\mathrm{Cl}^{-}$, a $3 \mathrm{M} \mathrm{KCl}$ agar bridge was used. All experiments were conducted at room temperature. Solutions were rapidly changed close to the cells or excised patches using multibarrel glass tubes. Each tube composing the multibarrel had an internal diameter of $0.9 \mathrm{~mm}$ (Vitro Dynamics, Trenton, NJ, USA). Changes between different solutions were performed using the Perfusion Fast-Step SF-77B (Warner Instrument Corp., Holliston, MA, USA).

For IV relations in the inside-out configuration, we exposed the patches to $\mathrm{Ca}^{2+}$ containing solution for $1 \mathrm{~s}$ at $+100 \mathrm{mV}$ and then applied a ramp from +80 to $-80 \mathrm{mV}$ at $0.36 \mathrm{mV} / \mathrm{ms}$. Leak currents measured in nominally $0 \mathrm{Ca}^{2+}$ solution were subtracted. The reversal potential $\left(E_{\text {rev }}\right)$ was estimated by using a fit with the polynomial function $I=a_{1}+$ $a_{2} V+a_{3} V^{2}+a_{4} V^{3}+a_{5} V^{4}+a_{6} V^{5}+a_{7} V^{6}$, where $I$ is the current, $V$ is the voltage and $a_{i}$ are numerical parameters.

For whole-cell recordings of tail currents, the protocol consisted of voltage steps of $500 \mathrm{~ms}$ duration from a holding potential of $0 \mathrm{mV}$ to $+80 \mathrm{mV}$ followed by voltage steps ranging from -20 to $+50 \mathrm{mV}$. A single-exponential function $\left(I=A_{1} \exp \left(-t / t_{1}\right)\right)$, was fitted to tail currents to extrapolate the tail current value at the beginning of the step. Tail current values were plotted as a function of voltage, and $E_{\text {rev }}$ was estimated using a fit with a polynomial function.

To measure dose-responses and ion selectivity, currents in whole-cell were measured at the time they reached the maximal activation as shown in Figure $1 \mathrm{~A}-\mathrm{C}$, while experiments in inside-out were performed just after patch excision to avoid current rundown (Figure 1D,E). However, in patches with a slow rundown several recordings were obtained from the same patch.

Liquid junction potentials were calculated using the pClampex software (Axon Instruments, San Jose, CA, USA), and applied voltages were corrected off-line.

\subsection{Solutions}

Cells were kept in mammalian Ringer's solution composed of (in mM) $140 \mathrm{NaCl}$, $5 \mathrm{KCl}, 2 \mathrm{CaCl}_{2}, 1 \mathrm{MgCl}_{2}, 10$ glucose and 10 HEPES, pH 7.4 with $\mathrm{NaOH}$.

For whole-cell recordings, the pipette solution contained (in $\mathrm{mM}$ ) $140 \mathrm{NaCl}, 10 \mathrm{HEPES}$ and 10 HEDTA, pH 7.2 and $5.86,8.26$ or $9.26 \mathrm{mM} \mathrm{CaCl}_{2}$ to obtain $3.8,13$ or $30 \mu \mathrm{M}$ free $\mathrm{Ca}^{2+}$, respectively. For intracellular solutions containing $\mathrm{Ca}^{2+}$ concentrations $>30 \mu \mathrm{M}$ HEDTA was omitted and an appropriate amount of $\mathrm{CaCl}_{2}$ was used. For permeability experiments, cells were bathed with solution containing (in mM) $140 \mathrm{NaCl}$ and 10 HEPES, pH 7.4. NaCl was reduced to $14 \mathrm{mM}$ or replaced with N-Methyl-D-glucamine chloride (NMDG-Cl), sodium methanesulfonate (NaMeS) or sodium isothiocyanate (NaSCN). The osmolarity in the low $\mathrm{NaCl}$ solution was adjusted with sucrose.

For inside-out recordings, the pipette solution contained (in $\mathrm{mM}$ ) 140 (or 14) $\mathrm{NaCl}$, 5 EGTA and 10 HEPES, pH 7.2 with $\mathrm{NaOH}$. The patches were maintained in nominally $0 \mathrm{Ca}^{2+}$ solution containing (in mM) $140 \mathrm{NaCl}, 10$ HEDTA or 5 EGTA and 10 HEPES, pH 7.2. For dose-response relations, the bath solution was the same as that used in the pipette for whole-cell recordings. For permeability experiments using the dilution method, the bath solution contained (in mM) $140 \mathrm{NaCl}, 10$ HEPES and 0.1 or $1 \mathrm{mM} \mathrm{CaCl}_{2}$ and $\mathrm{NaCl}$ was changed to $280,70,28$, or $14 \mathrm{mM}$. The osmolarity in the low- $\mathrm{NaCl}$ solution was adjusted with sucrose. In some experiments, $\mathrm{NaCl}$ was replaced with NMDG-Cl, $\mathrm{NaMeS}$, $\mathrm{NaSCN}, \mathrm{NaBr}, \mathrm{NaNO}_{3}$ or NaI. All chemicals, unless otherwise stated, were purchased from Sigma-Aldrich (Milano, Italy).

\subsection{Data Analysis}

Data analysis and figures were made with IgorPro software (Wavemetrics, Lake Oswego, OR, USA). Data are presented as the mean \pm sem (standard error of the mean), 
with $\mathrm{n}$ indicating the number of cells or excides patches. The double exponential function used to fit the data in Figure 1D was $I=A_{1} \exp \left(-t / t_{1}\right)+A_{2} \exp \left(-t / t_{2}\right)$, where $t_{1}$ and $t_{2}$ are the time constants. The normality of the data was tested with the Shapiro-Wilk test, while the homogeneity of variance was tested with Levene's test. For normally distributed data, statistical significance was determined using paired unpaired $t$-tests or ANOVA as appropriate. When a statistically significant difference was determined with ANOVA, a post-hoc Tukey test or Dunnett test was performed to evaluate which data groups showed significant differences. For non-normally distributed data, we used the Wilcoxon-MannWhitney test. For multicomparison of the data we used Dunn-Hollander-Wolfe test after Kruskal-Wallis analysis. Data in Figure 2F were analysed using the methods developed by Crawford and Garthwaite [62] using R. $p$ values $<0.05$ were considered significant.

Supplementary Materials: The following are available online at https:/ / www.mdpi.com/article/10 $.3390 /$ ijms22168578/s1.

Author Contributions: Conceptualisation, S.S., S.P. and A.M.; methodology, S.S., S.P. and A.M.; software, S.P.; validation, S.S., S.P. and A.M.; formal analysis, S.S., S.P. and A.M.; investigation, S.S. and S.P.; resources, A.M.; data curation, S.S., S.P. and A.M.; writing-original draft preparation, S.P.; writing-review and editing, A.M. and S.S.; visualisation, S.P.; supervision, S.P. and A.M.; project administration, S.P. and A.M.; funding acquisition, A.M. All authors have read and agreed to the published version of the manuscript.

Funding: This research was funded by the Italian Ministry of Education, University and Research, grant number 2010599KBR to Anna Menini.

Institutional Review Board Statement: Not applicable.

Informed Consent Statement: Not applicable.

Data Availability Statement: The data that support the findings of this study are available from the corresponding author upon reasonable request.

Acknowledgments: We thank Lily Jan (UCSF, San Francisco, CA, USA) and Huanghe Yang (Duke University, Durham, NC, USA) for providing plasmids, Anna Boccaccio (CNR, Genova, Italy) and all members of the laboratory for helpful discussions.

Conflicts of Interest: The authors declare no conflict of interest. The funders had no role in the design of the study; in the collection, analyses, or interpretation of data; in the writing of the manuscript, or in the decision to publish the results.

\section{References}

1. Pedemonte, N.; Galietta, L.J.V. Structure and Function of TMEM16 Proteins (Anoctamins). Physiol. Rev. 2014, 94, 419-459. [CrossRef] [PubMed]

2. Whitlock, J.M.; Hartzell, H.C. Anoctamins/TMEM16 Proteins: Chloride Channels Flirting with Lipids and Extracellular Vesicles. Annu. Rev. Physiol. 2017, 79, 119-143. [CrossRef] [PubMed]

3. Falzone, M.E.; Malvezzi, M.; Lee, B.-C.; Accardi, A. Known Structures and Unknown Mechanisms of TMEM16 Scramblases and Channels. J. Gen. Physiol. 2018, 150, 933-947. [CrossRef] [PubMed]

4. Kalienkova, V.; Clerico Mosina, V.; Paulino, C. The Groovy TMEM16 Family: Molecular Mechanisms of Lipid Scrambling and Ion Conduction. J. Mol. Biol. 2021, 166941. [CrossRef] [PubMed]

5. Caputo, A.; Caci, E.; Ferrera, L.; Pedemonte, N.; Barsanti, C.; Sondo, E.; Pfeffer, U.; Ravazzolo, R.; Zegarra-Moran, O.; Galietta, L.J.V. TMEM16A, a Membrane Protein Associated with Calcium-Dependent Chloride Channel Activity. Science 2008, 322, 590-594. [CrossRef]

6. Yang, Y.D.; Cho, H.; Koo, J.Y.; Tak, M.H.; Cho, Y.; Shim, W.-S.; Park, S.P.; Lee, J.; Lee, B.; Kim, B.-M.; et al. TMEM16A Confers Receptor-Activated Calcium-Dependent Chloride Conductance. Nature 2008, 455, 1210-1215. [CrossRef]

7. Schroeder, B.C.; Cheng, T.; Jan, Y.N.; Jan, L.Y. Expression Cloning of TMEM16A as a Calcium-Activated Chloride Channel Subunit. Cell 2008, 134, 1019-1029. [CrossRef]

8. Pifferi, S.; Dibattista, M.; Menini, A. TMEM16B Induces Chloride Currents Activated by Calcium in Mammalian Cells. Pflüg. Arch. Eur. J. Physiol. 2009, 458, 1023-1038. [CrossRef]

9. Stephan, A.B.; Shum, E.Y.; Hirsh, S.; Cygnar, K.D.; Reisert, J.; Zhao, H. ANO2 Is the Cilial Calcium-Activated Chloride Channel That May Mediate Olfactory Amplification. Proc. Natl. Acad. Sci. USA 2009, 106, 11776-11781. [CrossRef] 
10. Benedetto, R.; Cabrita, I.; Schreiber, R.; Kunzelmann, K. TMEM16A Is Indispensable for Basal Mucus Secretion in Airways and Intestine. FASEB J. 2018, 33, 4502-4512. [CrossRef]

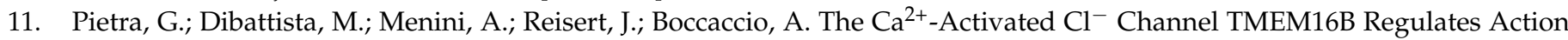
Potential Firing and Axonal Targeting in Olfactory Sensory Neurons. J. Gen. Physiol. 2016, 148, 293-311. [CrossRef]

12. Dibattista, M.; Pifferi, S.; Boccaccio, A.; Menini, A.; Reisert, J. The Long Tale of the Calcium Activated Cl- Channels in Olfactory Transduction. Channels Austin Tex. 2017, 11, 399-414. [CrossRef]

13. Amjad, A.; Hernandez-Clavijo, A.; Pifferi, S.; Maurya, D.K.; Boccaccio, A.; Franzot, J.; Rock, J.; Menini, A. Conditional Knockout of TMEM16A/Anoctamin1 Abolishes the Calcium-Activated Chloride Current in Mouse Vomeronasal Sensory Neurons. J. Gen. Physiol. 2015, 145, 285-301. [CrossRef] [PubMed]

14. Leblanc, N.; Forrest, A.S.; Ayon, R.J.; Wiwchar, M.; Angermann, J.E.; Pritchard, H.A.T.; Singer, C.A.; Valencik, M.L.; Britton, F.; Greenwood, I.A. Molecular and Functional Significance of $\mathrm{Ca}^{2+}$-Activated $\mathrm{Cl}^{-}$Channels in Pulmonary Arterial Smooth Muscle. Pulm. Circ. 2015, 5, 244-268. [CrossRef] [PubMed]

15. Suzuki, J.; Fujii, T.; Imao, T.; Ishihara, K.; Kuba, H.; Nagata, S. Calcium-Dependent Phospholipid Scramblase Activity of TMEM16 Protein Family Members. J. Biol. Chem. 2013, 288, 13305-13316. [CrossRef]

16. Suzuki, J.; Umeda, M.; Sims, P.J.; Nagata, S. Calcium-Dependent Phospholipid Scrambling by TMEM16F. Nature 2010, 468, 834-838. [CrossRef] [PubMed]

17. Bevers, E.M.; Williamson, P.L. Getting to the Outer Leaflet: Physiology of Phosphatidylserine Exposure at the Plasma Membrane. Physiol. Rev. 2016, 96, 605-645. [CrossRef]

18. Castoldi, E.; Collins, P.W.; Williamson, P.L.; Bevers, E.M. Compound Heterozygosity for 2 Novel TMEM16F Mutations in a Patient with Scott Syndrome. Blood 2011, 117, 4399-4400. [CrossRef]

19. Ehlen, H.W.A.; Chinenkova, M.; Moser, M.; Munter, H.-M.; Krause, Y.; Gross, S.; Brachvogel, B.; Wuelling, M.; Kornak, U.; Vortkamp, A. Inactivation of Anoctamin-6/Tmem16f, a Regulator of Phosphatidylserine Scrambling in Osteoblasts, Leads to Decreased Mineral Deposition in Skeletal Tissues. J. Bone Miner. Res. 2013, 28, 246-259. [CrossRef]

20. Batti, L.; Sundukova, M.; Murana, E.; Pimpinella, S.; De Castro Reis, F.; Pagani, F.; Wang, H.; Pellegrino, E.; Perlas, E.; Di Angelantonio, S.; et al. TMEM16F Regulates Spinal Microglial Function in Neuropathic Pain States. Cell Rep. 2016, 15, 2608-2615. [CrossRef]

21. Zaitseva, E.; Zaitsev, E.; Melikov, K.; Arakelyan, A.; Marin, M.; Villasmil, R.; Margolis, L.B.; Melikyan, G.B.; Chernomordik, L.V. Fusion Stage of HIV-1 Entry Depends on Virus-Induced Cell Surface Exposure of Phosphatidylserine. Cell Host Microbe 2017, 22, 99-110. [CrossRef] [PubMed]

22. Braga, L.; Ali, H.; Secco, I.; Chiavacci, E.; Neves, G.; Goldhill, D.; Penn, R.; Jimenez-Guardeño, J.M.; Ortega-Prieto, A.M.; Bussani, R.; et al. Drugs That Inhibit TMEM16 Proteins Block SARS-CoV-2 Spike-Induced Syncytia. Nature 2021, 594, 88-93. [CrossRef]

23. Yang, H.; Kim, A.; David, T.; Palmer, D.; Jin, T.; Tien, J.; Huang, F.; Cheng, T.; Coughlin, S.R.; Jan, Y.N.; et al. TMEM16F Forms a $\mathrm{Ca}^{2+}$-Activated Cation Channel Required for Lipid Scrambling in Platelets during Blood Coagulation. Cell 2012, 151, 111-122. [CrossRef]

24. Kunzelmann, K.; Nilius, B.; Owsianik, G.; Schreiber, R.; Ousingsawat, J.; Sirianant, L.; Wanitchakool, P.; Bevers, E.M.; Heemskerk, J.W.M. Molecular Functions of Anoctamin 6 (TMEM16F): A Chloride Channel, Cation Channel, or Phospholipid Scramblase? Pflug. Arch. 2014, 466, 407-414. [CrossRef] [PubMed]

25. Picollo, A.; Malvezzi, M.; Accardi, A. TMEM16 Proteins: Unknown Structure and Confusing Functions. J. Mol. Biol. 2015, 427, 94-105. [CrossRef]

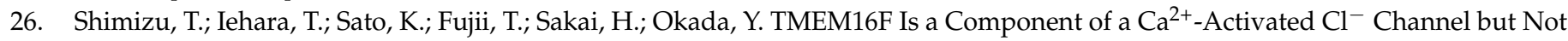
a Volume-Sensitive Outwardly Rectifying $\mathrm{Cl}^{-}$Channel. Am. J. Physiol. Cell Physiol. 2013, 304, C748-C759. [CrossRef]

27. Grubb, S.; Poulsen, K.A.; Juul, C.A.; Kyed, T.; Klausen, T.K.; Larsen, E.H.; Hoffmann, E.K. TMEM16F (Anoctamin 6), an Anion Channel of Delayed Ca ${ }^{2+}$ Activation. J. Gen. Physiol. 2013, 141, 585-600. [CrossRef]

28. Henkel, B.; Drose, D.R.; Ackels, T.; Oberland, S.; Spehr, M.; Neuhaus, E.M. Co-Expression of Anoctamins in Cilia of Olfactory Sensory Neurons. Chem. Senses 2015, 40, 73-87. [CrossRef] [PubMed]

29. Ousingsawat, J.; Wanitchakool, P.; Kmit, A.; Romao, A.M.; Jantarajit, W.; Schreiber, R.; Kunzelmann, K. Anoctamin 6 Mediates Effects Essential for Innate Immunity Downstream of P2X7 Receptors in Macrophages. Nat. Commun. 2015, 6, 6245. [CrossRef]

30. Aoun, J.; Hayashi, M.; Sheikh, I.A.; Sarkar, P.; Saha, T.; Ghosh, P.; Bhowmick, R.; Ghosh, D.; Chatterjee, T.; Chakrabarti, P.; et al. Anoctamin 6 Contributes to Cl- Secretion in Accessory Cholera Enterotoxin (Ace)-Stimulated Diarrhea: An essential role for phosphatidylinositol 4,5-bisphosphate (PIP2) signaling in cholera. J. Biol. Chem. 2016, 291, 26816-26836. [CrossRef] [PubMed]

31. Muratori, C.; Pakhomov, A.G.; Gianulis, E.; Meads, J.; Casciola, M.; Mollica, P.A.; Pakhomova, O.N. Activation of the Phospholipid Scramblase TMEM16F by Nanosecond Pulsed Electric Fields (NsPEF) Facilitates Its Diverse Cytophysiological Effects. J. Biol. Chem. 2017, 292, 19381-19391. [CrossRef] [PubMed]

32. Simões, F.; Ousingsawat, J.; Wanitchakool, P.; Fonseca, A.; Cabrita, I.; Benedetto, R.; Schreiber, R.; Kunzelmann, K. CFTR Supports Cell Death through ROS-Dependent Activation of TMEM16F (Anoctamin 6). Pflug. Arch. 2018, 470, 305-314. [CrossRef]

33. Kim, H.J.; Jun, I.; Yoon, J.S.; Jung, J.; Kim, Y.K.; Kim, W.K.; Kim, B.J.; Song, J.; Kim, S.J.; Nam, J.H.; et al. Selective Serotonin Reuptake Inhibitors Facilitate ANO6 (TMEM16F) Current Activation and Phosphatidylserine Exposure. Pflug. Arch. 2015, 467, 2243-2256. [CrossRef] [PubMed] 
34. Alvadia, C.; Lim, N.K.; Clerico Mosina, V.; Oostergetel, G.T.; Dutzler, R.; Paulino, C. Cryo-EM Structures and Functional Characterization of the Murine Lipid Scramblase TMEM16F. eLife 2019, 8, e44365. [CrossRef]

35. Nguyen, D.M.; Chen, L.S.; Yu, W.-P.; Chen, T.-Y. Comparison of Ion Transport Determinants between a TMEM16 Chloride Channel and Phospholipid Scramblase. J. Gen. Physiol. 2019, 151, 518-531. [CrossRef] [PubMed]

36. Ye, W.; Han, T.W.; He, M.; Jan, Y.N.; Jan, L.Y. Dynamic Change of Electrostatic Field in TMEM16F Permeation Pathway Shifts Its Ion Selectivity. eLife 2019, 8, e45187. [CrossRef]

37. Betto, G.; Cherian, O.L.; Pifferi, S.; Cenedese, V.; Boccaccio, A.; Menini, A. Interactions between Permeation and Gating in the TMEM16B/Anoctamin2 Calcium-Activated Chloride Channel. J. Gen. Physiol. 2014, 143, 703-718. [CrossRef]

38. Cenedese, V.; Betto, G.; Celsi, F.; Cherian, O.L.; Pifferi, S.; Menini, A. The Voltage Dependence of the TMEM16B/Anoctamin2 Calcium-Activated Chloride Channel Is Modified by Mutations in the First Putative Intracellular Loop. J. Gen. Physiol. 2012, 139, 285-294. [CrossRef]

39. Barry, P.H. The Reliability of Relative Anion-Cation Permeabilities Deduced from Reversal (Dilution) Potential Measurements in Ion Channel Studies. Cell Biochem. Biophys. 2006, 46, 143-154. [CrossRef]

40. Le, T.; Jia, Z.; Le, S.C.; Zhang, Y.; Chen, J.; Yang, H. An Inner Activation Gate Controls TMEM16F Phospholipid Scrambling. Nat. Commun. 2019, 10, 1846. [CrossRef]

41. Ye, W.; Han, T.W.; Nassar, L.M.; Zubia, M.; Jan, Y.N.; Jan, L.Y. Phosphatidylinositol-(4, 5)-Bisphosphate Regulates Calcium Gating of Small-Conductance Cation Channel TMEM16F. Proc. Natl. Acad. Sci. USA 2018, 115, E1667-E1674. [CrossRef] [PubMed]

42. Yu, K.; Duran, C.; Qu, Z.; Cui, Y.-Y.; Hartzell, H.C. Explaining Calcium-Dependent Gating of Anoctamin-1 Chloride Channels Requires a Revised Topology. Circ. Res. 2012, 110, 990-999. [CrossRef] [PubMed]

43. Yu, K.; Whitlock, J.M.; Lee, K.; Ortlund, E.A.; Cui, Y.Y.; Hartzell, H.C. Identification of a Lipid Scrambling Domain in ANO6/TMEM16F. eLife 2015, 4, e06901. [CrossRef]

44. Di Zanni, E.; Gradogna, A.; Scholz-Starke, J.; Boccaccio, A. Gain of Function of TMEM16E/ANO5 Scrambling Activity Caused by a Mutation Associated with Gnathodiaphyseal Dysplasia. Cell. Mol. Life Sci. CMLS 2018, 75, 1657-1670. [CrossRef] [PubMed]

45. Whitlock, J.M.; Yu, K.; Cui, Y.Y.; Hartzell, H.C. Anoctamin 5/TMEM16E Facilitates Muscle Precursor Cell Fusion. J. Gen. Physiol. 2018, 150, 1498-1509. [CrossRef]

46. Lin, H.; Roh, J.; Woo, J.H.; Kim, S.J.; Nam, J.H. TMEM16F/ANO6, a Ca ${ }^{2+}$-Activated Anion Channel, Is Negatively Regulated by the Actin Cytoskeleton and Intracellular MgATP. Biochem. Biophys. Res. Commun. 2018, 503, 2348-2354. [CrossRef]

47. Scudieri, P.; Caci, E.; Venturini, A.; Sondo, E.; Pianigiani, G.; Marchetti, C.; Ravazzolo, R.; Pagani, F.; Galietta, L.J.V. Ion Channel and Lipid Scramblase Activity Associated with Expression of TMEM16F/ANO6 Isoforms. J. Physiol. 2015, 593, 3829-3848. [CrossRef]

48. Fakler, B.; Adelman, J.P. Control of K(Ca) Channels by Calcium Nano/Microdomains. Neuron 2008, 59, 873-881. [CrossRef]

49. Takeuchi, H.; Kurahashi, T. Second Messenger Molecules Have a Limited Spread in Olfactory Cilia. J. Gen. Physiol. 2018, 150, 1647-1659. [CrossRef]

50. Adomaviciene, A.; Smith, K.J.; Garnett, H.; Tammaro, P. Putative Pore-Loops of TMEM16/Anoctamin Channels Affect Channel Density in Cell Membranes. J. Physiol. 2013, 591, 3487-3505. [CrossRef]

51. Jiang, T.; Yu, K.; Hartzell, H.C.; Tajkhorshid, E. Lipids and Ions Traverse the Membrane by the Same Physical Pathway in the NhTMEM16 Scramblase. eLife 2017, 6, e28671. [CrossRef]

52. Sachs, F. Stretch-Activated Ion Channels: What Are They? Physiology 2010, 25, 50-56. [CrossRef] [PubMed]

53. Pathak, M.M.; Tran, T.; Hong, L.; Joós, B.; Morris, C.E.; Tombola, F. The Hv1 Proton Channel Responds to Mechanical Stimuli. J. Gen. Physiol. 2016, 148, 405-418. [CrossRef] [PubMed]

54. Brohawn, S.G.; Su, Z.; MacKinnon, R. Mechanosensitivity Is Mediated Directly by the Lipid Membrane in TRAAK and TREK1 K+ Channels. Proc. Natl. Acad. Sci. USA 2014, 111, 3614-3619. [CrossRef]

55. Yang, T.; Colecraft, H.M. Calmodulin Regulation of TMEM16A and 16B Ca2+-Activated Chloride Channels. Channels 2015, 10, 38-44. [CrossRef]

56. Jung, J.; Nam, J.H.; Park, H.W.; Oh, U.; Yoon, J.-H.; Lee, M.G. Dynamic Modulation of ANO1/TMEM16A HCO3(-) Permeability by $\mathrm{Ca}^{2+}$ /Calmodulin. Proc. Natl. Acad. Sci. USA 2013, 110, 360-365. [CrossRef]

57. Yu, Y.; Chen, T.-Y. Purified Human Brain Calmodulin Does Not Alter the Bicarbonate Permeability of the ANO1/TMEM16A Channel. J. Gen. Physiol. 2015, 145, 79-81. [CrossRef]

58. Huang, F.; Wang, X.; Ostertag, E.M.; Nuwal, T.; Huang, B.; Jan, Y.-N.; Basbaum, A.I.; Jan, L.Y. TMEM16C Facilitates Na ${ }^{+}-$Activated $^{2}$ $\mathrm{K}^{+}$Currents in Rat Sensory Neurons and Regulates Pain Processing. Nat. Neurosci. 2013, 16, 1284-1290. [CrossRef]

59. Pan, B.; Akyuz, N.; Liu, X.-P.; Asai, Y.; Nist-Lund, C.; Kurima, K.; Derfler, B.H.; György, B.; Limapichat, W.; Walujkar, S.; et al. TMC1 Forms the Pore of Mechanosensory Transduction Channels in Vertebrate Inner Ear Hair Cells. Neuron 2018, 99, 736-753. [CrossRef] [PubMed]

60. Ávalos Prado, P.; Häfner, S.; Comoglio, Y.; Wdziekonski, B.; Duranton, C.; Attali, B.; Barhanin, J.; Sandoz, G. KCNE1 Is an Auxiliary Subunit of Two Distinct Ion Channel Superfamilies. Cell 2021, 184, 534-544. [CrossRef]

61. Dulin, N.O. Calcium-Activated Chloride Channel ANO1/TMEM16A: Regulation of Expression and Signaling. Front. Physiol. 2020, 11, 590262. [CrossRef] [PubMed]

62. Crawford, J.R.; Garthwaite, P.H. Using Regression Equations Built from Summary Data in the Neuropsychological Assessment of the Individual Case. Neuropsychology 2007, 21, 611-620. [CrossRef] [PubMed] 